\title{
A CONSTRUÇÃO INSTITUCIONAL DA POLÍTICA COMERCIAL BRASILEIRA: A CÂMARA DE COMÉRCIO EXTERIOR(CAMEX) NO GOVERNO CARDOSO'
}

\author{
Ivan Filipe de Almeida Lopes Fernandes
}

\begin{abstract}
RESUMO
O objetivo deste trabalho é analisar o processo de construção das instituições que regeram a política de comércio exterior no Brasil durante o governo Cardoso, tendo como foco as relações entre a mudança institucional e a dinâmica político burocrática interna ao Poder Executivo, com o qual avaliamos as condições nas quais o conflito burocrático é uma variável importante no processo de mudança institucional. Dado que o comércio exterior é uma atividade ampla, optamos por analisar as reformas realizadas sobre o seu quadro de coordenação: os processos de formação e reformas da Câmara de Comércio Exterior (CAMEX). Desenvolvemos na primeira parte do trabalho um arcabouço analítico a partir de uma avaliação breve e crítica do que já foi produzido sobre a influência e as implicações da participação da burocracia no jogo político, do qual derivamos as hipóteses de pesquisa. Em seguida, analisamos o papel exercido pelo conflito interno ao Poder Executivo entre as diferentes agências envolvidas com a política comercial e como foi a ação da Presidência. Propomos, finalmente, que o conflito e a disputa entre burocracias foi um fator determinante para a instabilidade institucional e para a consolidação de um formato subótimo, que encontra dificuldades no cumprimento das funções de coordenação do comércio exterior brasileiro. A partir da proposição de um novo arcabouço teórico que concatena diferentes debates a respeito da política burocrática, derivamos a proposição central da pesquisa que reside na expectativa de como as interações entre os atores políticos e burocráticos dentro do Poder Executivo afetam os resultados dos processos decisórios sobre mudança institucional.
\end{abstract}

PALAVRAS-CHAVE: política comercial; mudança institucional; política burocrática; conflito burocrático.

\section{INTRODUÇÃO}

O objetivo deste artigo é analisar o processo de construção das instituições que regeram a política de comércio exterior durante o governo Cardoso, tendo como foco as relações entre a mudança institucional e a dinâmica político-burocrática interna ao poder Executivo.

Neste estudo são avaliadas as condições nas quais o conflito burocrático é uma variável importante no processo de mudança institucional. Demonstramos que o conflito e a disputa entre burocracias foi um fator determinante para a instabilidade institucional e para a consolidação de um formato subótimo, que encontra dificuldades no cumprimento das funções de coordenação do comércio exterior brasileiro. Dado que o comércio exterior é uma atividade ampla, analisamos as reformas no seu quadro de coordenação: os

\footnotetext{
1 Agradecemos os comentários dos pareceristas anônimos da Revista de Sociologia e Política.
}

processos de formação e reformas da institucionalidade do modelo de coordenação política centrado na Câmara de Comércio Exterior (Camex).

Adota-se como marco teórico o prisma analítico da política burocrática e o quadro de questões analisadas ao longo do estudo é composto pelas relações e conflitos entre as agências e órgãos burocráticos com interesses nas arenas nas quais a política comercial foi realizada. O termo "política burocrática" refere-se às implicações do papel político exercido pelas burocracias. Ao longo dos últimos anos, inúmeras correntes da literatura trataram do tema. Entre essas, incluímos os mais diversos campos como os estudos organizacionais, análises sobre as relações entre burocratas e políticos e sobre a autonomia burocrática, estudos sobre os processos de implementação de políticas públicas, as relações entre burocracias e grupos de interesse ou mesmo estudos sobre os determinantes e as conseqüências do conflito entre burocracias.

Buscamos contribuir com a literatura que trata da 
política burocrática propondo um novo modelo sobre as relações internas do poder Executivo e de suas implicações empíricas e teóricas, uma vez que esse tema não é freqüentemente abordado na literatura. Diagnóstico semelhante foi feito por Figueiredo (2010) a respeito da literatura brasileira. A autora entende que estudos contemplando o poder Executivo, do ponto de vista de sua estrutura institucional, são inexistentes na Ciência Política brasileira. Dito isso, procuramos contribuir para reduzir essa importante lacuna.

Durante a reflexão teórica, atenção especial foi dada ao fato de que a literatura que trata da política burocrática foi construída tendo como base empírica o caso estadunidense. Dado isso, propomos uma análise a partir de uma realidade distinta desse sistema e em uma política pública que no Brasil é caracterizada por ser desenvolvida dentro do poder Executivo. Ressaltamos que o foco concentra-se nas relações internas do Executivo de modo que os constrangimentos externos que não se refletem dentro do próprio Executivo não são levados em conta no arcabouço analítico proposto.

$\mathrm{O}$ artigo está dividido em cinco seções, incluindo esta introdução. Na próxima, apresentamos as correntes da literatura que trataram do tema e desenvolvemos conceitos imprescindíveis para a análise. Na terceira, resumimos o quadro analítico que articula as relações entre os atores políticos e burocráticos dentro do poder Executivo e em quais circunstâncias o conflito burocrático emerge. Depois, apresentamos as hipóteses adotadas. Na quarta seção, utilizando-se dos conceitos desenvolvidos, discorremos sobre a dinâmica dos processos decisórios ${ }^{2}$ que tiveram influência na constituição e consolidação da Camex. Por fim, na última seção, reunimos os achados empíricos e teóricos.

\section{ASPECTOS TEÓRICOS DA POLÍTICA BURO- CRÁTICA}

A burocracia tornou-se um importante ator no cenário político e o seu crescimento e expansão qualitativa devem ser considerados fenômenos políticos de primeira grandeza. Contudo, apesar dessa importância, a literatura que estuda a burocracia e suas implicações produziu menos informações sistemáticas sobre esse aspecto do governo do que de qualquer

\footnotetext{
2 Definimos "processo decisório" como o processo político formado por dois momentos distintos na produção de uma política pública: $(i)$ o processo de formulação no qual a decisão sobre qual curso de ação política a ser adotado é tomada e (ii) o processo de implementação no qual a política escolhida é transformada em política efetiva.
}

outro. Enquanto eleições, partidos e legislativos foram extensivamente analisados, aspectos administrativos do governo e suas implicações políticas foram deixados de lado, de modo que ainda não temos boas ferramentas teóricas e conceituais para compreender a política burocrática (MEIER, 1979; PETERS, 1995).

Foram desenvolvidos conceitos que trataram a política burocrática em duas direções. Na primeira, os esforços foram investidos na análise das relações entre as agências burocráticas e os grupos de interesse e clientelas (SELZNICK, 1949; CARDOSO, 1974). Já no segundo, o foco esteve nas relações entre as agências e os atores políticos que devem controlá-las (BREWER, 2008), sendo três correntes principais que analisaram o processo de interação entre burocracia e agentes políticos.

A primeira é a corrente da teoria da escolha pública aplicada à análise da burocracia, que fez uso da economia política e do individualismo metodológico para a construção de seus modelos teóricos sobre o comportamento de burocracias e burocratas. A orientação básica indica que as agências seriam compostas de indivíduos racionais que atuariam de modo a promover a sua própria agenda. Os burocratas são retratados como maximizadores de orçamento e as burocracias são, por definição, organizações expansionistas que buscam aumentar seu tamanho, equipe, financiamentos e/ou tarefas (TULLOCK, 1965; DOWNS, 1966; NISKANEN, 1971; GOODIN, 1975; DUNLEAVY, 1991).

A segunda é uma análise herdeira de conceitos oriundos da administração pública e analisa o comportamento das burocracias e suas relações com atores políticos pela vertente da questão organizacional. Essa abordagem enfatiza a natureza da ação organizacional, entendida como a estrutura organizacional, o processamento coordenado de atividades, os limites impostos pelos controles e atores externos sobre essas organizações e um conjunto maior de preferências e preocupações que moldam e estimulam o comportamento e a ação individual dos burocratas (MEIER, 1979; ROURKE, 1979; WILSON, 1989).

$\mathrm{Na}$ terceira foram aplicados princípios microeconômicos para a análise do problema do controle político das burocracias, sendo que uma das aplicações mais relevantes foi a teoria do agenteprincipal, com a qual se defendeu a tese que políticos possuem instrumentos suficientes para controlar os outputs burocráticos, mas cuja utilização é custosa de recursos e tempo, e o controle político excessivo pode gerar ineficiência na provisão de serviços (WEINGAST \& MORAN, 1983; MCCUBBINS \& SCHWARTZ, 
1984; MOE, 1984; 1985; WEINGAST, 1984; MILLER, 2005).

Apesar das três correntes terem analisado a política burocrática de ângulos interessantes e trazido luzes sobre as articulações entre a política e a burocracia, um tema primordial foi deixado de lado. A política burocrática inclui também conflitos, barganhas e compromissos entre as organizações burocráticas e políticas nas fases de decisão e implementação, envolvendo chefes e funcionários das burocracias e atores políticos interessados. Um dos principais modelos sobre o conflito burocrático foi produzido na literatura de "análise de política externa", na qual foi desenvolvido o conceito do "governo burocrático", inaugurado por Hilsman (1959), Neustadt (1960), Huntington (1961), Schiling (1962), Welch (1992) e consagrado por Allison em seu clássico Essence of Decision (ALLISON, 1971) ${ }^{3}$.

Allison (idem) propôs três abordagens para iluminar a natureza do processo decisório. A primeira seria o paradigma do ator racional e unitário. A segunda é o paradigma organizacional, no qual o estado é um conglomerado de organizações semifeudais, frouxamente aliadas, cada uma com vida própria e autônoma. As ações estatais são decorrentes dos outputs organizacionais, sendo determinadas por programas, rotinas e procedimentos operacionais padrões das burocracias envolvidas na decisão e implementação da política. O terceiro modelo é o do governo burocrático, no qual o comportamento estatal é determinado pela barganha e compromisso ao longo de circuitos regularizados de comunicação, que permitem a interação entre os atores posicionados em pontos chaves dentro das arenas decisórias (ALLISON \& HALPERIN, 1972).

O paradigma burocrático delimita-se à análise do processo decisório dentro do poder Executivo. Nesses modelos, a exclusão do poder Legislativo e dos grupos de interesse é analítica, não significando que a interação entre os poderes seja uma variável inexpressiva nos sistemas políticos do ponto de vista empírico (HALPERIN, 1974).

Allison e Halperin (1972) refinaram o modelo ao observarem dois momentos no processo decisório: os jogos de decisão e de implementação. O primeiro jogo é a arena principal, onde são tomadas as decisões políticas, enquanto o segundo é a arena na qual as políticas são implantadas. O segundo apresenta características herdadas do paradigma organizacional

\footnotetext{
3 Cf. também Allison (1969) e Allison e Zelikow (1999).
}

e os procedimentos também se tornam instrumentos de influência nas decisões tomadas nos jogos de decisão.

A principal crítica ao modelo burocrático é sobre a minimização da força do chefe de governo. Os críticos sugerem que o modelo não leva em conta o poder estrutural decorrente do poder de nomeação do chefe de governo (KRASNER, 1972; FREEDMAN, 1976). Rosati (1981) observou padrões distintos que não são captados pelas abordagens burocráticas e do poder estrutural. Ambas não avaliam o nível de envolvimento do chefe de governo, que é variável chave para a diferenciação da análise, pois este possui recursos para moldar o processo decisório de acordo com suas preferências. No entanto, isso só acontece se ele decide envolver-se de maneira direta na questão.

\section{FONTES DO PODER BUROCRÁTICO}

O poder que uma burocracia é capaz de congregar é uma variável fundamental dentro da abordagem burocrática. No entanto, poder burocrático é um termo impreciso, assim como todos os conceitos que lidam com a questão do poder. Estando cientes dessas limitações, adotaremos o conceito de Meier (1979), no qual o poder burocrático refere-se à capacidade da burocracia em alocar de maneira autônoma e impositiva os recursos, sendo, portanto, o poder político exercido pela burocracia em termos de sua capacidade de determinar ou influenciar, de acordo com seus interesses, o processo decisório sobre quem ganha o que, quando e como, seja provendo com recursos, seja impondo despesas, regulações e sanções ${ }^{4}$.

Entre os recursos externos utilizados por uma agência para a obtenção de poder burocrático, o apoio político e os recursos financeiros, definidos em termos de suas apropriações orçamentárias, são os mais importantes. Já os recursos internos relacionam-se com características básicas do funcionamento de uma agência e interferem de maneira direta na sua capacidade de desenvolver um cenário dentro do processo de formulação de políticas que favoreça a promoção dos seus interesses, tendo basicamente três distintas fontes: o grau de conhecimento específico exigido na execução de suas tarefas (expertise), as especificidades do processo de implementação das políticas e o grau de coesão dos burocratas.

\footnotetext{
4 Tomamos como base de nossa definição de poder burocrático a definição de poder de Lasswell e Kaplan (1950) de que o poder é a participação no processo decisório. De acordo com esses autores: "G tem poder sobre $\mathrm{H}$ com relação aos valores $\mathrm{K}$, se $\mathrm{G}$ participa da tomada de decisões que afetam as políticas de $\mathrm{H}$ relativas a K".
} 


\section{AMOTIVAÇÃO BUROCRÁTICA}

Uma derivação da motivação dos burocratas utilizada na literatura, e que também distancia as preferências dos burocratas do interesse público, é o pressuposto de que os interesses individuais são os interesses paroquiais da agência e estão de acordo com a Lei de Miles, que aponta que "o que você defende depende de onde você está posicionado". A posição ocupada pelo indivíduo determinaria suas preferências. Com base nesse pressuposto, a escolha pública generalizou o interesse conjunto das agências e dos burocratas em torno da expansão de orçamentos, de modo que teriam uma tendência inexorável a maximizá-los.

Outra corrente propôs que os interesses dos burocratas estão associados com as oportunidades de carreira. Os interesses coincidem com os da agência apenas nas situações em que a carreira está intimamente conectada com a sobrevivência da própria agência. Isto é, quando a ascensão da carreira dá-se dentro da agência. Nessa corrente, os interesses dependem de onde os burocratas vieram e para onde vão. Embora desejem verbas, renda, prestígio, poder organizacional, eles estão dispostos a sacrificar benefícios no curto prazo para atingir resultados no longo prazo em relação a suas carreiras. As variáveis fundamentais que influenciam a formação da preferência burocrática são derivadas dos constrangimentos organizacionais e institucionais em relação às carreiras (SCHNEIDER, 1993; 1995).

\section{QUADRO ANAIÍTICO E PERCURSO METODO- LÓGICO}

\section{V.1. Uma tipologia sobre processos decisórios no poder Executivo}

Diante do exposto, explicitamos sumariamente o quadro analítico apresentando as condições necessárias para o surgimento do conflito burocrático e como este se relaciona com a evolução institucional da política comercial $^{5}$. Definimos que os burocratas são os agentes não eleitos do poder Executivo e que a política burocrática ocorre quando eles entram na arena política e buscam influenciar o processo decisório. Esse processo é caracterizado pelo conflito e barganha entre os múltiplos atores do poder Executivo que lutam pelo controle ou participação em um mesmo espaço e pela jurisdição ou competências sobre esferas políticas, nas quais buscam produzir ou pelo menos induzir a criação de condições favoráveis para a satisfação de suas preferências, tanto no processo de formulação quanto

\footnotetext{
5 Discussão mais detalhada do quadro analítico é apresentada em Fernandes (2011b).
}

na implementação de políticas públicas e reformas institucionais.

A primeira condição necessária para compreenderse o papel do conflito entre burocracias é o nível de envolvimento presidencial efetivo. Conforme vimos, uma das críticas ao modelo burocrático é que o chefe do governo possui um papel fundamental na organização, abertura e fechamento de espaços para as diferentes agências, o que lhe garante instrumentos para superar constrangimentos impostos pelas burocracias. Como demonstrado pela literatura do agente - principal, o chefe de governo ao ser responsável pela delegação de funções e tarefas para a burocracia possui instrumentos para controlá-la, desde que desenhe os incentivos institucionais corretos que constranjam a margem de escolha dos agentes. Ademais o chefe de governo é o garantidor da autonomia das agências, sendo factível a sua interferência $a d$ hoc. Em virtude disto, a influência da política burocrática é seriamente limitada quando interesses prioritários da presidência de República estão em disputa.

No entanto, o nível de envolvimento presidencial efetivo só não é baixo quando o chefe de governo está disposto a arcar com os custos do monitoramento das ações das burocracias e de obtenção das informações e conhecimentos para a formulação, implementação e condução da política e com os custos de oportunidade do tempo e dos recursos gastos com o monitoramento de ações de certas burocracias e não de outras. Quanto mais o envolvimento presidencial efetivo estiver voltado para certas políticas públicas, menos atenção estará disponível para o monitoramento das outras. É certo que os temas prioritários do jogo político estão imunes ao conflito burocrático e o seu processo decisório é marcado pela "dominância presidencial".

A segunda condição necessária para o surgimento do conflito burocrático é o grau do diferencial de poder entre agências que possuam interesses envolvidos no processo decisório. Caso este diferencial seja grande, o nível de conflito burocrático é baixo. A agência que possui mais poder terá sua preferência privilegiada e conseguirá impor-se no processo decisório, enquanto a menos poderosa não implantará sua agenda e nem poderá exigir que o processo de tomada de decisão seja de barganha, acomodação ou compromisso. Por outro lado, se o diferencial de poder for pequeno e os interesses contraditórios, o conflito será maior. Ambas tentarão implementar uma parte de sua agenda e provavelmente uma solução de barganha, acomodação e compromisso será necessária.

O poder burocrático é de natureza complexa e de fontes múltiplas. No entanto, há um recurso que supera todos outros: o apoio político da Presidência da 
República. Quando o presidente respalda de maneira inequívoca as ações de uma burocracia, ela pode utilizar todos os instrumentos e poderes que a posição de chefe do poder Executivo oferece e somá-los aos poderes inerentes a si mesma, como controle de recursos humanos, financeiros, expertise e a capacidade de tratar informações, podendo impor com facilidade suas decisões sobre as outras burocracias que participam do processo decisório. Ademais, quando o apoio político do presidente a uma burocracia é total, esta burocracia está na situação de maior poder possível dentro do poder Executivo. Os únicos constrangimentos que lhe são impostos durante o processo decisório são externos ao Executivo.

A terceira condição necessária para o surgimento do conflito burocrático é o nível de divergência entre as burocracias sobre determinada decisão política. Somente quando houver interesses burocráticos conflitantes em relação a determinado processo, há espaço para o surgimento do conflito. Caso a decisão seja aceita ou partilhada por todos atores envolvidos ou se envolver apenas um, estaremos diante de processos consensuais ou questão interna.

Adotando o foco das carreiras de Schneider (1993; 1995), o grau de divergência está relacionado com o quanto as carreiras dos burocratas estão comprometidas com a decisão em questão e o quanto os interesses da clientela da agência impactam na carreira dos seus membros. Como nosso objeto empírico são reformas institucionais, essas questões naturalmente sobressaem-se. As mudanças institucionais tendem a afetar o rol de competências e responsabilidades das burocracias, seu status dentro da administração e sua capacidade de controlar recursos para a consecução de atividades, interesses, objetivos e de manipular e estimular a participação de sua clientela. Isso afeta a capacidade de sobrevivência da própria agência ou de algumas de suas partes no longo prazo e as possibilidades de ascensão na carreira por parte de seus membros.

$\mathrm{Na}$ análise de interesses dos burocratas é importante observar como as carreiras são desenhadas e o quanto da vida profissional é passada na agência. Quanto mais as carreiras estejam relacionadas com uma única agência, mais os burocratas traduzem seus interesses em termos paroquiais e corporativistas. Por outro lado, quanto menos estruturadas, maior é a tendência de o burocrata perseguir objetivos externos aos defendidos na agência. Por fim, parte dos interesses de uma é derivada dos interesses da clientela que gravita em torno dela. Assim, é necessário analisar o quanto as decisões em pauta afetam os interesses da clientela, quais são os canais de interação entre esta e os burocratas e o quão importante, à agência e aos burocratas, é o apoio político dessa clientela.

Diante do exposto, resumimos o arcabouço analítico no seguinte quadro, combinando as três condições (de maneira dicotômica) e resultando em seis tipos distintos de processos decisórios:

QUADRO 1 - TIPOLOGIA SOBRE OS PROCESSOS DECISÓRIOS INTERNOS AO PODER EXECUTIVO

\begin{tabular}{|c|c|c|c|}
\hline \multirow{2}{*}{$\begin{array}{c}\text { Envolvimento } \\
\text { presidencial efetivo }\end{array}$} & \multirow{2}{*}{$\begin{array}{c}\text { Diferencial de } \\
\text { poder burocrático }\end{array}$} & \multicolumn{2}{|c|}{ Divergência de interesse } \\
\hline & & SIM & NÃO \\
\hline \multirow{2}{*}{$\begin{array}{l}\text { Alto (dominância } \\
\text { presidencial) }\end{array}$} & Alto & $\begin{array}{c}\text { Imposição presidencial } \\
\text { subtipo I }\end{array}$ & \multirow{2}{*}{ Consenso presidencial } \\
\hline & Baixo & $\begin{array}{c}\text { Imposição presidencial } \\
\text { subtipo II }\end{array}$ & \\
\hline \multirow{2}{*}{$\begin{array}{l}\text { Baixo (dominância } \\
\text { burocrática) }\end{array}$} & Alto & Imposição burocrática & \multirow{2}{*}{$\begin{array}{c}\text { Concordância burocrática } \\
\text { ou questão interna }\end{array}$} \\
\hline & Baixo & Conflito burocrático & \\
\hline
\end{tabular}

FONTE: O autor.

A metade superior do quadro delimita os casos nos quais o nível de envolvimento presidencial efetivo é alto e o processo decisório é marcado pela dominância presidencial, havendo três subtipos de processos marcados por um interesse e envolvimento presidencial efetivo: as imposições presidenciais de subtipo I e subtipo II e o consenso presidencial. Esse tipo e seus subtipos de processos só ocorrem em um número limitado de caso: os prioritários na agenda do governante e nos quais a presidência dedica total atenção, monitorando constantemente os passos das burocracias.

A imposição presidencial de subtipo I descreve o 
processo que ocorre quando o presidente está efetivamente envolvido em uma política que possui uma burocracia muito mais poderosa em relação às outras e que possui uma posição contrária à vontade da Presidência da República. Embora a burocracia mais poderosa possa advogar uma postura diferente daquela defendida na presidência, ela tende a adequar-se à posição presidencial, pois, caso contrário, será minada e/ou enfraquecida. Isso porque o alto envolvimento efetivo do presidente mina qualquer possibilidade de surgimento de conflito burocrático, pois ao presidente sempre lhe faculta a posição de adotar os instrumentos que lhe forem necessários para impor sua posição dentro do poder Executivo.

Já a imposição presidencial de subtipo II descreve o processo decisório que corre quando o presidente está efetivamente envolvido em uma questão, investindo seus esforços para a obtenção da decisão desejada e existem algumas burocracias que disputam espaço no processo de decisão. A ação presidencial mina e minimiza o potencial conflito, premiando a agência cuja posição mais se aproxima da posição do chefe do poder Executivo. Nos casos em que um dos atores burocráticos permanece com uma posição contrária, ele será enfraquecido e relegado a um segundo. A reforma institucional torna-se então orientada pela ação presidencial e pela burocracia que melhor acolhe suas proposições.

Por fim, nas situações marcadas pelo consenso presidencial, a presidência está efetivamente envolvida e não há divergência entre ela e as burocracias. Todos os atores interessados possuem a mesma posição sobre a questão e, portanto, não há espaço para o surgimento do conflito, pois não há divergências entre as partes. Como nessa situação atípica não há burocracia com posição contrária à presidencial, nenhuma será enfraquecida ou terá sua capacidade de ação de longo prazo alterada. Dessa forma, nesse subtipo de processo decisório, a reforma é orientada pela ação orquestrada da presidência e das burocracias.

A metade inferior delimita casos mais corriqueiros, nos quais o nível de envolvimento presidencial é reduzido, abrindo espaço para a ação autônoma da burocracia. Esses processos decisórios são de dominância burocrática e compõe a maior parte das decisões. Os principais atores são as burocracias afetadas e interessadas e o presidente exerce papel marginal, muito mais de árbitro de conflitos do que de ator político interessado. Apesar de o envolvimento presidencial efetivo ser baixo e a presidência apresentar-se como um órgão de arbitragem de conflitos, ele não é nulo. A burocracia que for capaz de ativar o apoio presidencial tornar-se-á privilegiada em relação às outras. Nesses casos, as reformas institucionais tenderão a favorecer essa burocracia. Três tipos de processos com dominância burocrática emergem: imposição burocrática, conflito burocrático e concordância burocrática ou questão interna.

Quando o presidente não estiver envolvido no processo decisório e uma burocracia possuir recursos mais amplos que outras (sendo que o apoio presidencial é a maior fonte de poder de uma burocracia), ela imporá sua vontade. Mesmo que haja oposição, o diferencial de poder não permite que outras agências barganhem ou acomodem a decisão. Nesse caso estamos diante de uma imposição burocrática e a reforma institucional é orientada pela burocracia mais poderosa.

Por outro lado, quando o nível de envolvimento presidencial efetivo for baixo, o diferencial de poder for baixo e houver divergências entre as burocracias, estaremos em um processo de conflito burocrático. $\mathrm{O}$ resultado final desse processo é fruto da barganha e compromisso ao longo de circuitos de comunicação, que permitem a interação entre atores estatais chaves, posicionados hierarquicamente dentro do governo. A decisão e implementação são os vetores finais da interação entre os atores para os quais uma decisão tem implicações. O comportamento estatal decorrerá nessa situação de um intrincado jogo de barganha, acomodação e compromisso entre os atores situados nas posições chaves do poder Executivo (que nem sempre possuem objetivos e métodos convergentes). Os equilíbrios obtidos serão inerentemente instáveis, uma vez que quaisquer alterações na correlação de forças entre as burocracias em conflito gerarão pequenas alterações nas decisões finais obtidas.

Por fim, quando o presidente não estiver efetivamente envolvido e não houver divergências entre as burocracias, estaremos em uma situação marcada pela concordância burocrática, que por definição estará livre do conflito. Um caso especial são os processos que interessam a apenas uma agência, sendo, portanto, uma questão interna que não interessa a nenhum outro órgão. Nesses processos, a reforma é orientada pela ação solitária ou pela ação orquestrada das burocracias.

\section{V.2. Proposição de pesquisa}

A partir do arcabouço teórico, derivaremos a proposição central da pesquisa. A hipótese refere-se às expectativas em relação a como esperamos que as interações entre atores políticos do Executivo e as agências burocráticas executivas afetem o resultado dos processos decisórios que efetivaram as mudanças institucionais no quadro de coordenação na política comercial brasileira no governo Cardoso. Esperamos que as mudanças institucionais em ambientes burocráticos conflituosos tendam a formar agências institucionalmente instáveis no curto prazo. Isto porque, o equilí- 
brio que produz a decisão é sensível às alterações na correlação de forças entre as burocracias. A instabilidade institucional da política comercial durante o governo Cardoso, de acordo com o prisma analítico proposto, teria suas raízes na natureza conflituosa do seu processo decisório.

\section{A CÂMARA DE COMÉRCIO EXTERIOR NO GOVERNO CARDOSO}

\section{VI.1. A criação da Camex}

O que sobrou da era Carteira de Comércio Exterior do Banco do Brasil (Cacex), principal agência de formulação da política comercial desenvolvimentista, após o vendaval da abertura econômica e das reformas realizadas pelo governo de Fernando Collor de Mello, foi um arcabouço institucional pulverizado, com sobreposição e partilha de competências e ausência de um organismo coordenador das ações dos ministérios e agências. A debilidade era acentuada por não ser uma das prioridades do governo de Itamar Franco, no qual toda atenção fora destinada para a questão da estabilidade monetária. Conforme pode ser identificado na Figura 1 abaixo, três ministérios dividiam as principais incumbências e não havia nenhuma instituição de intermediação para resolver questões que envolvessem competências partilhadas ${ }^{6}$.

FIGURA 1 -APARATO INSTITUCIONAL DA POLIITICA COMERCIAL NO GOVERNO ITAMAR FRANCO

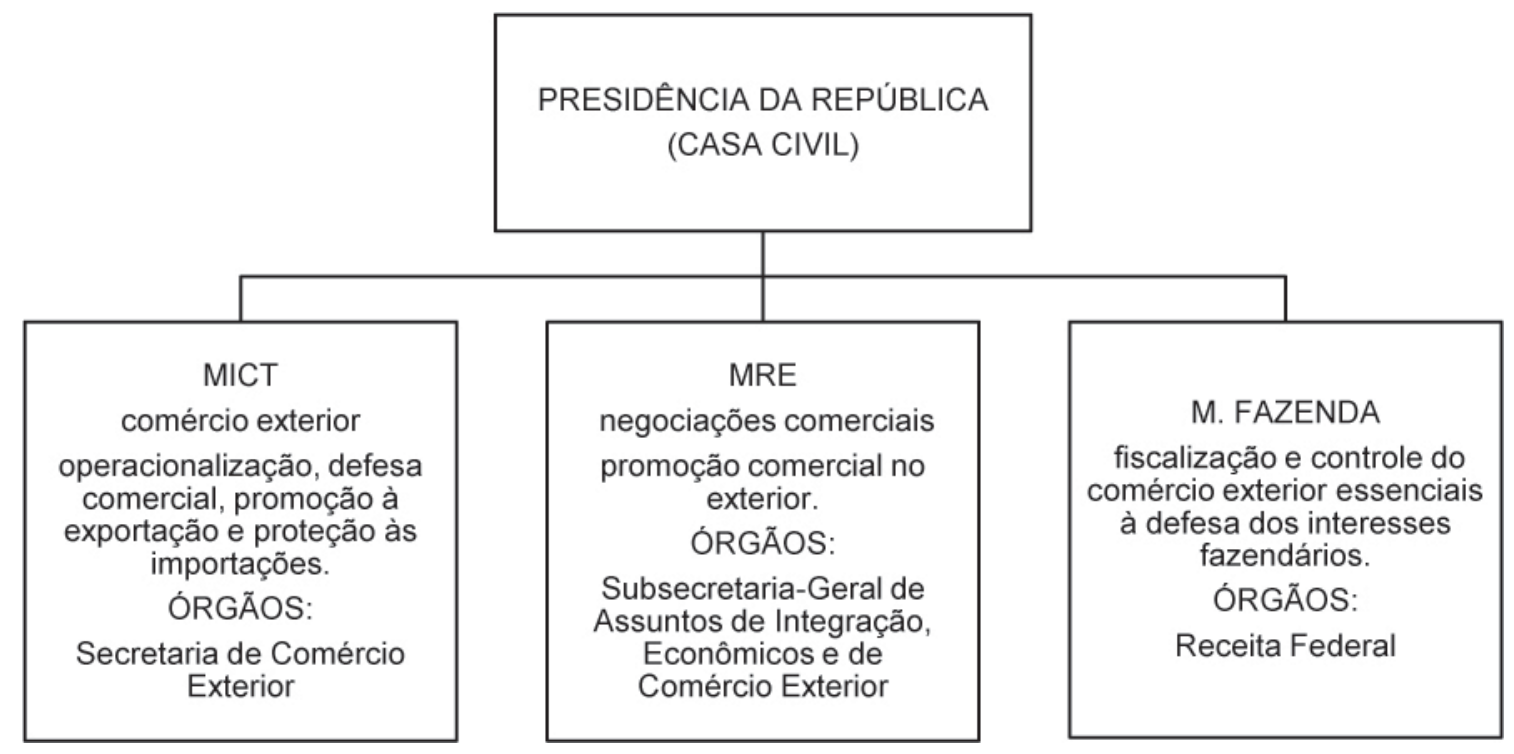

FONTE: O autor, a partir da Lei n. 8 490, de 19 de novembro de 1992.

Diante desse quadro de sobreposição institucional e buscando superá-lo, foi criada em 1995, no governo de Fernando Henrique Cardoso, a Câmara de Comércio Exterior (Camex), vinculada ao Conselho de Governo da Presidência da República. Essa câmara foi montada para ser o foro consultivo de discussão e consolidação das posições dos diferentes ministérios, servindo como um ponto focal de diálogo intraburocrático, além de ter a incumbência de definir as diretrizes e orientar as políticas de promoção às exportações, defesa comercial e negociações comerciais internacionais.

A Camex era composta por dois órgãos: a Secretaria Executiva, incumbida da organização dos trabalhos e rotinas diárias da agência e a própria Câmara de Ministros, órgão máximo do comércio exterior brasileiro. O secretário executivo era nomeado pelo presidente, enquanto a Câmara era integrada pelo ministro da Casa
Civil, que representava a presidência e pelos ministérios das Relações Exteriores (MRE); Fazenda (MF); Indústria, Comércio e Turismo (MICT); Planejamento, Orçamento e Gestão (MP); Agricultura, Pecuária e Abastecimento e Ministério do Abastecimento ${ }^{7}$.

\footnotetext{
6 Para maiores informações sobre a política comercial brasileira no período desenvolvimentista, as reformas liberais do presidente Fernando Collor de Mello e o governo Itamar Franco, cf. Fernandes (2011a; 2011b).

7 O Decreto n. 1386 , de 6 de fevereiro de 1995, que criou a Camex, foi assinado pelo presidente Fernando Henrique Cardoso e pelos seis ministros membros, a saber: Clóvis Carvalho, Luiz Felipe Lampreia, Pedro Malan, Dorothéa Werneck, José Serra e José Eduardo de Andrade Vieira, em uma demonstração, pelo menos formal, da não preponderância de nenhum dos ministros sobre os outros em matéria de comércio exterior
} 
A presidência da Câmara foi exercida nos primeiros anos pelo ministro da Casa Civil, Clóvis Carvalho. E, segundo relato do próprio presidente em livro de memórias, o papel de Carvalho dentro do governo era de articulação administrativa e não política, devendo, portanto, envolver-se com a partilha de poder administrativo entre os ministérios e não na relação entre o Congresso e o poder Executivo ou entre os partidos que compunham a coalizão (CARDOSO, 2006). Ademais, é importante frisar que a posição de Carvalho como articulador administrativo estendia-se para todo o governo, e não apenas à política comercial. A sua incumbência como presidente da Câmara era menor entre as inúmeras atividades cotidianas exercidas pelo ministro $^{8}$.

A Camex não assumiu atribuições operacionais sobre a política comercial. As competências dos ministérios envolvidos foram mantidas, inaugurando um estilo de coordenação interministerial sem controle da implementação. $\mathrm{O}$ modelo atendia à proposta do diplomata brasileiro Rubens Barbosa, que, partindo do diagnóstico da ausência de uma estrutura de coordenação durante o governo Franco, propusera o fortalecimento de mecanismos coordenativos em um núcleo reduzido, desburocratizado, com dedicação integral e vinculado à Presidência da República. Ele sublinhara que o órgão não deveria assumir competências próprias, pois o sucesso desse inédito modelo de coordenação na política comercial dependeria da aceitação dos ministérios, que não se disporiam facilmente a abrir mão de suas competências na temática (BARBOSA, 1994).

Em seu desenho original, a Camex, além de ser ligada à presidência, estava instalada no Palácio do
Planalto, o que lhe dava um grande poder convocatório. Suas reuniões possuíam a simbologia presidencial, sendo prestigiadas pelos ministros que a compunha, mesmo sem possuir competências operacionais que lhe permitissem tomar decisões impositivas. Segundo relato de um assessor especial que trabalhou na Camex em seus primeiros anos, esse momento inicial foi de profunda riqueza criativa, mesmo na ausência de competências formais para a realização de políticas efetivas. Nesse período, importantes instituições que se consolidaram nos anos seguintes foram criadas, entre elas, a Agência de Promoção às Exportações (APEX) e a Seguradora Brasileira de Crédito (SBCE). Segundo entrevista com ex-assessor especial, a Camex cumpriu um papel de catalisador de reorganização institucional do comércio exterior, sendo uma espécie de think tank público para a política comercial.

A opção pela criação de uma instituição coordenadora sem poderes operacionais foi adotada, pois a criação de um ministério específico esbarraria nas resistências dos outros ministérios em repartir competências, recursos financeiros e humanos. Os maiores focos de resistência viriam do Ministério da Fazenda e do MRE. O primeiro perderia o poder de fixar tarifas aduaneiras e o segundo temia, além de perder poder na coordenação das negociações comerciais internacionais, ter de ceder parte de seu pessoal treinado, pois não havia quadros suficientes dentro da administração pública federal para prestar os serviços requeridos a um Ministério de Comércio Exterior (FRANÇA, 1997).

Com a criação da Camex, a configuração institucional do comércio exterior brasileiro ficou com a formatação demonstrada na Figura 2:

FIGURA 2 -APARATO INSTITUCIONAL DA POLITICA COMERCIAL NO $1^{\circ}$ MANDATO DO GOVERNO CARDOSO

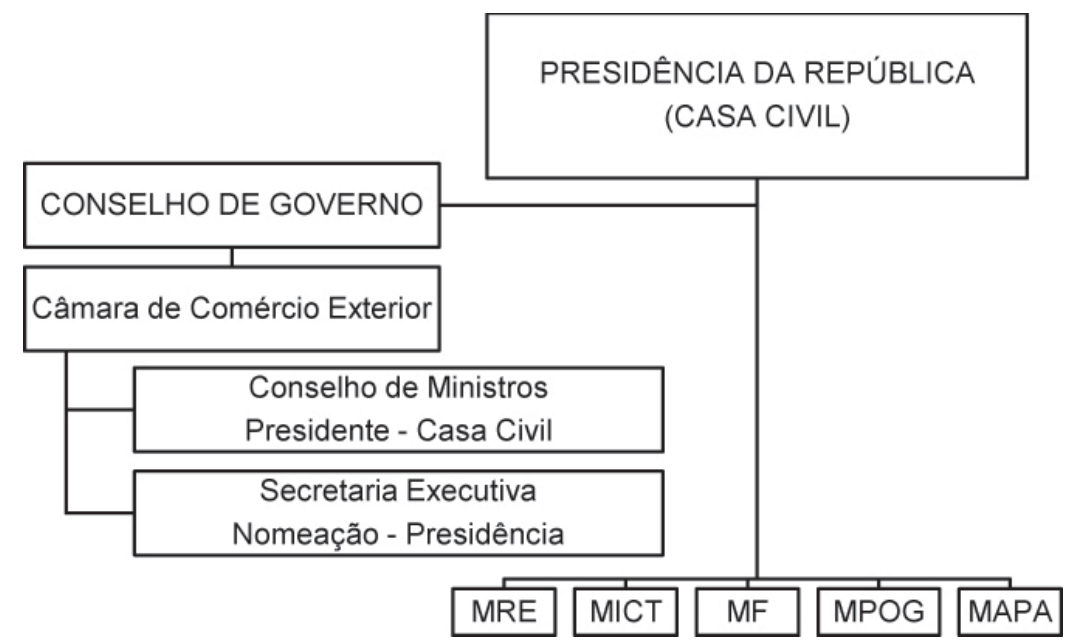

FONTE: O autor, a partir do Decreto n. 1 386, de 6 de fevereiro de 1995.

8 Entrevista com Clóvis de Barros Carvalho, realizada em 13 de julho de 2010 . 
Ademais, durante os primeiros anos da Camex não houve esforços por parte da Presidência da República para superar as resistências burocráticas. A atuação de Fernando Henrique Cardoso no processo de criação da Camex foi tímida. A reforma institucional dessa política não estava entre as prioridades. Algumas evidências sobre isso podem ser tomadas ao analisar-se os 246 discursos feitos pelo presidente em 1995, publicados na compilação Palavra do Presidente (CARDOSO, s. d.), nos quais não há nenhum que trate de questões institucionais envolvendo a política comercial e mesmo em sua proposta de governo "Mãos à Obra", publicada nas eleições de 1994, não há referências sobre a institucionalidade de coordenação da política. A única questão institucional tratada foi sobre a criação, no âmbito da Secretaria de Comércio Exterior do MICT (Secex), do Departamento de Defesa Comercial.

Diante das posições contrárias a qualquer reforma mais agressiva, e do não envolvimento presidencial, a Camex foi uma solução de consenso para resolver o problema da dispersão e pulverização institucional, sem agredir os interesses dos ministérios envolvidos com temas conexos. Foi uma solução limitada pela situação de conflito burocrático que emergiu dentro da estrutura institucional após a reforma em negativo feita no governo Collor.

O modelo não exigiu maiores investimentos de capital político por parte da Presidência da República, que priorizava as políticas voltadas para a estabilização da economia e também não criou na Camex um locus que abrisse espaços na política econômica para ministérios menos envolvidos com o Plano Real, ainda mais se levarmos em conta que a política de importação, uma das principais faces da política comercial, foi um dos mecanismos usados para estimular as políticas de contenção de preços.

Podemos concluir até o momento que a solução institucional encontrada com a criação da Camex visava reduzir o problema da falta de coordenação sem afetar as competências e interesses dos outros ministérios. A primeira fase da Camex, que foi estável durante todo o primeiro mandato de Fernando Henrique Cardoso, foi operada, portanto, em um marco de concordância burocrática. Por mais que houvesse o veto do MRE e do Ministério da Fazenda à criação de um Ministério do Comércio Exterior, em nenhum momento opuseramse à Camex, pois o modelo coordenador não ameaçava suas competências. Ademais, a criação da agência foi facilitada pelo fato da proposta ter sido realizada nos primeiros meses do governo, que é um momento propício para a criação de novas instituições ${ }^{9}$.

\footnotetext{
9 Segundo relato do embaixador Sérgio Amaral, em entrevista
}

O resultado dessa primeira reforma foi a criação de um foro consultivo sem capacidade de imposição de decisões, servindo mais como um espaço de reflexão interministerial do que uma instituição operadora de políticas. O que era aprovado na Camex podia ser alterado ou vetado pelos ministérios competentes na fase de implementação. Durante a criação da Camex, portanto, não houve intervenção presidencial e nem choque entre burocracias com interesses distintos.

\section{VI.2. Um primeiro esboço de reforma}

Em 1998 esse cenário começa a mudar com a indicação do secretário de Política Econômica do MF, José Roberto Mendonça de Barros, para o posto de secretário executivo da Camex. Essa indicação integrava um amplo projeto de alteração da dinâmica dos objetivos e métodos da política econômica. Entre outras mudanças planejadas, a Camex seria fortalecida como organismo formulador e executor da política comercial. O principal fator que motivava a presidência a aprofundar o papel exercido pela Câmara era a necessidade de coordenação da retomada do crescimento das exportações brasileiras com a remontagem de políticas voltadas para a promoção comercial e às exportações.

As dificuldades enfrentadas no balanço de pagamentos com o aumento das importações e com as altas taxas de juros decorrentes da política monetária anti-inflacionária do primeiro mandato requeriam esforços de recuperação de saldos positivos da balança comercial de modo a complementar o ajuste fiscal, viabilizar um acerto mais rápido nas contas públicas e avançar no processo de reestruturação produtiva nacional. Os saldos comerciais haviam sido sucessivamente negativos devido aos fluxos de importações decorrentes da política de valorização cambial do Plano Real (VEIGA, 2007).

Durante a passagem de Barros pela Camex, a agência foi fortalecida como órgão formulador principal da política comercial. Barros e a Camex foram apoiados pelo presidente, que, por sua vez, participou com mais freqüência de reuniões da Câmara ${ }^{10}$. A nova concepção da Camex seria um arranjo informal para substituir o projeto de criação de um Ministério de Comércio Exterior (PINTO, 1998). E mais, de acordo com relato de Prado (2005), um grupo de burocratas formado

realizada em 25 de junho de 2010, a proposta de criação da Camex teve origem em planos do próprio embaixador e do então ministro do Planejamento José Serra.

10 Entrevista com ex-assessor especial da Camex, realizada em 22 de junho de 2010. 
por José Roberto Mendonça de Barros (secretário executivo da Camex), Luis Carlos Mendonça de Barros (ministro das comunicações) e André Lara Resende (presidente do Banco Nacional de Desenvolvimento Econômico e Social, BNDES) esteve em constante contato com o presidente no segundo semestre de 1998, formando uma espécie de equipe econômica paralela que ganhava força dentro do governo, e sob os auspícios da Presidência da República, com o fim de reformatar o projeto de política econômica do governo Cardoso.

O fortalecimento da Camex seria parte de um novo rumo dado à orientação da política econômica do governo por meio da criação de um Ministério da Produção, que englobaria e fortaleceria o MICT e cuja perna no comércio exterior seria a própria Camex. A tarefa desse novo Ministério da Produção seria formular uma política industrial mais ativa, com ampla utilização de instrumentos microeconômicos e setoriais e capaz de fazer frente aos desafios decorrentes das crises financeiras do final da década de 1990, sem afetar a estabilidade monetária alcançada pelo Plano Real, o principal ativo político de Fernando Henrique Cardoso. Nas freqüentes reuniões da equipe econômica paralela, definiam-se as bases de uma nova política econômica para o segundo mandato. Luis Carlos seria o ministro da Produção e homem forte do governo, ocupando o espaço político pertencente à equipe econômica da Fazenda, chefiada ao longo de todo o governo Cardoso por Pedro Sampaio Malan.

No entanto, o projeto foi abortado com o escândalo dos grampos do BNDES em novembro de 1998. No entendimento de Prado (idem), uma das razões do estouro do escândalo era que o Ministério da Produção tornar-se-ia muito forte ao integrar em uma mesma pasta órgãos como o BNDES, Camex e, talvez, até mesmo o Banco do Brasil. As articulações realizadas pela equipe econômica paralela desagradaram membros do governo próximos e mais distantes da Presidência da República. O desfecho da crise foi o desfazer desta, com o pedido de demissão conjunto de Luis Carlos, José Roberto e Lara Resende.

Em uma demonstração da frágil tessitura burocrática desses primeiros anos da Camex, após o pedido de demissão de Mendonça de Barros, o presidente não nomeou um substituto imediato. $\mathrm{O}$ cargo ficou desocupado por dois meses e somente no início do segundo mandato o embaixador José Botafogo Gonçalves, então ministro do MICT, foi nomeado para ser secretário executivo da Câmara. A razão da demora fora justificada pelo então porta-voz da presidência, Sérgio Amaral, o primeiro secretário executivo da Camex em 1995, pela ausência de rotinas burocráticas a serem executadas, uma vez que era uma instância de articulação política e não de execução de ações (SUBSTITUIÇÕES FICAM PARA DEPOIS, 1998).

Esse episódio deixou claro que o fortalecimento da Camex durante a passagem de Barros não resultou em fortalecimento institucional. A maior presença do presidente Fernando Henrique Cardoso na Câmara foi resultado da proximidade pessoal de seu líder e não de uma nova postura para com a política comercial. Por outro lado, embora o projeto de fortalecimento da Camex tenha fracassado, o episódio foi uma primeira demonstração dos conflitos que surgiriam sobre o controle do comércio exterior, ainda que a origem essencial do conflito fosse uma disputa sobre os rumos a serem tomado na política econômica do governo, envolvendo, portanto, questões muito mais amplas que aquelas concernentes ao nosso objeto de estudo.

A natureza consensual dos projetos envolvendo o comércio exterior elaborados na Camex, que definiu as políticas do primeiro mandato, exauriu-se com o aumento da tensão entre a equipe econômica do Plano Real e seus opositores dentro do próprio governo. Estes últimos encarnavam as propostas da equipe paralela dos Mendonça de Barros para o fortalecimento de políticas microeconômicas e setoriais, entre as quais estavam as políticas de promoção e financiamento às exportações. Aos poucos, o ambiente de consenso burocrático, no qual a Camex havia sido criada, cedeu espaço para um forte conflito burocrático entre o Ministério da Fazenda e o futuro Ministério do Desenvolvimento (antigo MICT).

Grosso modo, os "monetaristas" eram os economistas do governo mais alinhados com aquilo que ficou conhecido como pensamento neoliberal, defendiam um papel mais acentuado do mercado e menos intervencionista do Estado, com a adoção de políticas industriais horizontais e uma atitude mais draconiana contra elevações da inflação e menos sensível a reduções nas taxas de crescimento econômico de curto prazo. Do outro lado da contenda, os "desenvolvimentistas" eram os economistas que defendiam uma ação mais incisiva do governo para estimular a economia, adotando medidas setoriais que estimulassem o crescimento da indústria nacional e uma política de juros e tributária que sufocasse menos o setor produtivo nacional, sendo menos sensíveis às alterações na inflação e mais preocupados com as taxas de crescimento de curto prazo. Os principais representantes do governo de cada posição seriam do lado monetarista o ministro Pedro Malan e os presidentes do Banco Central Gustavo Franco e Gustavo Loyola e, do lado desenvolvimentista, os irmãos Mendonça de Barros e o ministro José Serra (POLÊMICA SOBRE O FUTURO, 1999). 
Essa disputa traria enorme instabilidade para a institucionalidade coordenadora do comércio exterior. Até o final do segundo mandato de Fernando Henrique Cardoso, três importantes reformas foram realizadas, mudando o status institucional da Camex dentro da administração e cujo resultado final não foi idealizado por nenhum dos participantes do processo decisório. $\mathrm{O}$ resultado institucional final foi o vetor resultante e inesperado das barganhas e compromissos entre os atores estatais chaves do Ministério da Fazenda, do Desenvolvimento e de outros ministérios membros do Conselho de Ministros da Camex e envolvidos com temas conexos ao comércio exterior. Como preconizado no modelo analítico apresentado na seção três, no qual a disputa político burocrática é conflituosa quando o envolvimento presidencial e o diferencial de poder entre atores com interesses divergentes são reduzidos.

\section{VI.3. A primeira grande reforma}

Mesmo após a saída da equipe econômica paralela, Fernando Henrique Cardoso anunciou a criação de um novo ministério, mas com outra denominação: o Ministério do Desenvolvimento, Indústria e Comércio (MDIC). Em discurso na CNI, em dezembro de 1998, o presidente anunciou a criação do MDIC, que englobaria, além do MICT, o BNDES, a Suframa (Superintendência da Zona Franca de Manaus), o Banco do Nordeste e o Banco da Amazônia. Esse ministério teria como missão formular políticas industriais e de exportação e ser o ativo administrativo de estímulo ao crescimento econômico. O nomeado para a titularidade desse ministério foi Celso Lafer. Contudo, sua gestão foi breve, durando apenas seis meses. Nesse curto período, Lafer não se apresentou como um contraponto à política econômica do Ministério da Fazenda. Essa postura valeu-lhe críticas e falta de apoio por parte do empresariado, justamente a forte clientela do MDIC, que permite que esse ministério, em certas ocasiões, enfrente de maneira mais firme o Ministério da Fazenda, mesmo este último sendo institucional e burocraticamente mais forte. Enfim, a nomeação de Lafer não trouxe perspectivas de inflexão nas políticas econômicas do governo com a adoção de medidas que dessem melhores condições de competitividade ao produtor nacional, que fora até então prejudicado pelas políticas econômicas do Ministério da Fazenda, que focavam em primeiro plano a estabilização monetária (EMPRESÁRIOS CRITICAM DISCURSO, 1999).

Em julho de 1999, o presidente Fernando Henrique

11 Entrevista concedida ao autor em 22 de junho de 2010.
Cardoso promoveu uma ampla reforma ministerial da qual Lafer não resistiu, pois não tinha apoio da base partidária do governo e muito menos da poderosa clientela do MDIC (LINS, 1999). Nessa reforma aconteceu a primeira grande mudança na Camex. O sucessor de Lafer foi o então ministro da Casa Civil, Clóvis Carvalho, que, ao deixar-lá, levou a Secretaria Executiva e a presidência do Conselho de Ministros da Camex para o MDIC, cuja denominação passou a ser Ministério do Desenvolvimento, Indústria e Comércio Exterior. Ainda, segundo relato de Lafer, ao assumir o Ministério do Desenvolvimento, o ministro Clóvis Carvalho requisitara a incorporação da Camex ao MDIC para fortalecer a capacidade deste ministério em produzir políticas mais assertivas de estímulo à exportação $^{11}$. A razão dessa alteração foi dada em declaração do presidente à imprensa, na qual demonstrou um planejamento em torno do fortalecimento da política de comércio exterior por meio da reestruturação produtiva e da expansão das exportações (CARDOSO, 1999).

Por outro lado, com essa transferência, o status institucional da Camex tornou-se assaz ambíguo. Ao mesmo tempo em que era um órgão colegiado interministerial, sua Secretaria Executiva encontravase no organograma de um ministério setorial (VEIGA \& IGLESIAS, 2002; RAMOS, 2008) ${ }^{12}$. Isto porque as atividades da Camex ainda estruturavam-se no modelo inicial, não podendo usurpar as competências do Ministério da Fazenda e do MRE, o que deixava claro como o novo posicionamento do fórum no MDIC era potencialmente conflituoso. Essas restrições são evidentes, pois em todos os decretos da Camex publicados a partir de 2001 constam limitações às suas competências nos campos de atuação da Fazenda e do MRE.

Em relação ao Ministério da Fazenda, os decretos que criam e reformam a Camex indicam que ela deve respeitar o exposto no artigo 237 da Constituição Federal, que dispõe sobre o controle e a fiscalização do comércio exterior e competências do Conselho Monetário Nacional e do próprio Ministério da Fazenda, no que toca à política de financiamento e de seguro às exportações. Já sobre o MRE, a Camex tem estipulado que no âmbito da promoção comercial e da

\footnotetext{
12 De acordo com reportagens na mídia, a alteração do locus da Camex teve participação fundamental de Carvalho, que, ao ser nomeado para o MDIC, levou-a consigo (RAMOS, 2008). Ademais, segundo relatos de ex-assessores da Camex, a transferência deste órgão da Casa Civil para o MDIC foi em muito dependente da idiossincrasia de Clóvis Carvalho, que considerava a Camex uma de suas maiores obras no governo Fernando Henrique Cardoso.
} 
representação do governo na Alca, Mercosul e OMC, as competências de coordenação são do MRE.

Com o desenrolar dos fatos, o potencial conflito entre o Ministério da Fazenda e o Ministério do Desenvolvimento tomou corpo e espaço. Os membros do governo que criticavam a política econômica encontraram no MDIC um abrigo para fazer oposição interna. Ressalvamos que isso não significa que o conflito dentro do governo Cardoso tenha começado aí. A criação do MDIC foi um evento na disputa entre desenvolvimentistas e monetaristas. $\mathrm{O}$ fato crucial era que, no MDIC, os desenvolvimentistas encontraram um abrigo institucional que lhes conferia maior musculatura na disputa com os monetaristas.

Além disso, as questões em jogo excediam o campo da política comercial. Havia uma forte disputa sobre como orientar a política econômica como um todo. $\mathrm{O}$ comércio exterior era, no debate entre desenvolvimentistas e monetaristas, apenas uma pequena faceta da desavença. Mas, mesmo assim, o conflito teve fortes reverberações no comércio exterior e na Camex. O foro de discussão interministerial vislumbrado na Camex transformava-se, então, em uma agência à disposição dos interesses da burocracia desenvolvimentista. Isso posto, ainda que a ida da Camex ao MDIC tenha fortalecido esse ministério, a Câmara tornou-se menos apta à coordenar o comércio exterior, reduzindo suas ambições a assuntos mais limitados às políticas de importação e exportação, conforme relatamos abaixo.

Mas em um sinal da fraqueza política do MDIC em relação às forças monetaristas, mesmo com a incorporação da Camex e do BNDES, Carvalho, que fora o principal líder administrativo do primeiro mandato, deixou o ministério em menos de dois meses devido às repercussões dos primeiros enfrentamentos com $o$ Ministério da Fazenda. Em um seminário sobre "Desenvolvimento e Estabilidade", promovido pelo Instituto Teotônio Vilela, do próprio partido de Fernando Henrique Cardoso, o PSDB, Carvalho criticou duramente a política econômica do Ministério da Fazenda, dizendo que "ajustes não podem ser entendidos como camisa de força para iniciativas voltadas para o desenvolvimento, o excesso de cautela a essas alturas será o outro nome para covardia" (MEIRELES, 1999). Segundo entrevista concedida pelo presidente Fernando Henrique Cardoso ao jornalista Geneton Moraes (2005), a demissão de Carvalho foi necessária para proteger a política econômica, em um momento de grande sensibilidade do mercado ${ }^{13}$. "[Carvalho] era o chefe

13 O ano de 1999 foi um momento de grande perturbação da Casa Civil; tinha ido para o ministério do Desenvolvimento e Indústria. De repente, por uma infelicidade, a mídia colocou um choque entre ele e o ministro da Fazenda, Pedro Malan. Eu tinha de apoiar a política financeira. Clóvis era um sujeito excepcional. Tive de chamá-lo, eu mesmo: 'Clóvis, não dá mais"” (idem).

Esse acontecimento deixou claro que, por mais que em seus discursos a Presidência da República apresentasse novos horizontes na política macroeconômica, as prioridades não haviam mudado. No momento de tensificação do conflito entre as burocracias do Ministério do Desenvolvimento e do Ministério da Fazenda, a presidência inevitavelmente defendeu os interesses da última. As restrições externas ao poder Executivo, originadas nos mercados e nas crises financeiras internacionais, impediam-no de adotar medidas que afetassem a credibilidade e estabilidade econômica do país. As prioridades estavam associadas aos interesses defendidos pela equipe de Malan. As demonstrações de apoio de Fernando Henrique Cardoso ao MDIC eram sempre refutadas quando essas agências entravam em rota de colisão com a burocracia fazendária, principalmente quando os embates envolviam temas referentes aos rumos da política econômica.

Além das restrições impostas à presidência e a todo governo sobre a necessidade de manutenção da credibilidade econômica do país, não podemos desconsiderar o fato de que mesmo sendo incitado a estimular o debate sobre a política econômica, o Ministério do Desenvolvimento é sensivelmente mais fraco que o Ministério da Fazenda do ponto de vista de sua estruturação institucional e em razão dos recursos burocráticos disponíveis. O Ministério da Fazenda é, sem sombra de dúvidas, o ministério mais forte entre todos os que estão envolvidos com temas do comércio exterior. Alguns dados a respeito dos recursos burocráticos disponíveis ao Ministério da Fazenda são apresentados a seguir.

econômica devido às crises financeiras nos países emergentes que reduziu substantivamente o fluxo de capitas estrangeiros para a economia brasileira, culminando com o fim do câmbio fixo e a forte depreciação cambial em janeiro de 1999. 
GRÁFICO 1 - DESPESAS DISCRICIONÁRIAS TOTAIS (EM R\$ BILHÕES)

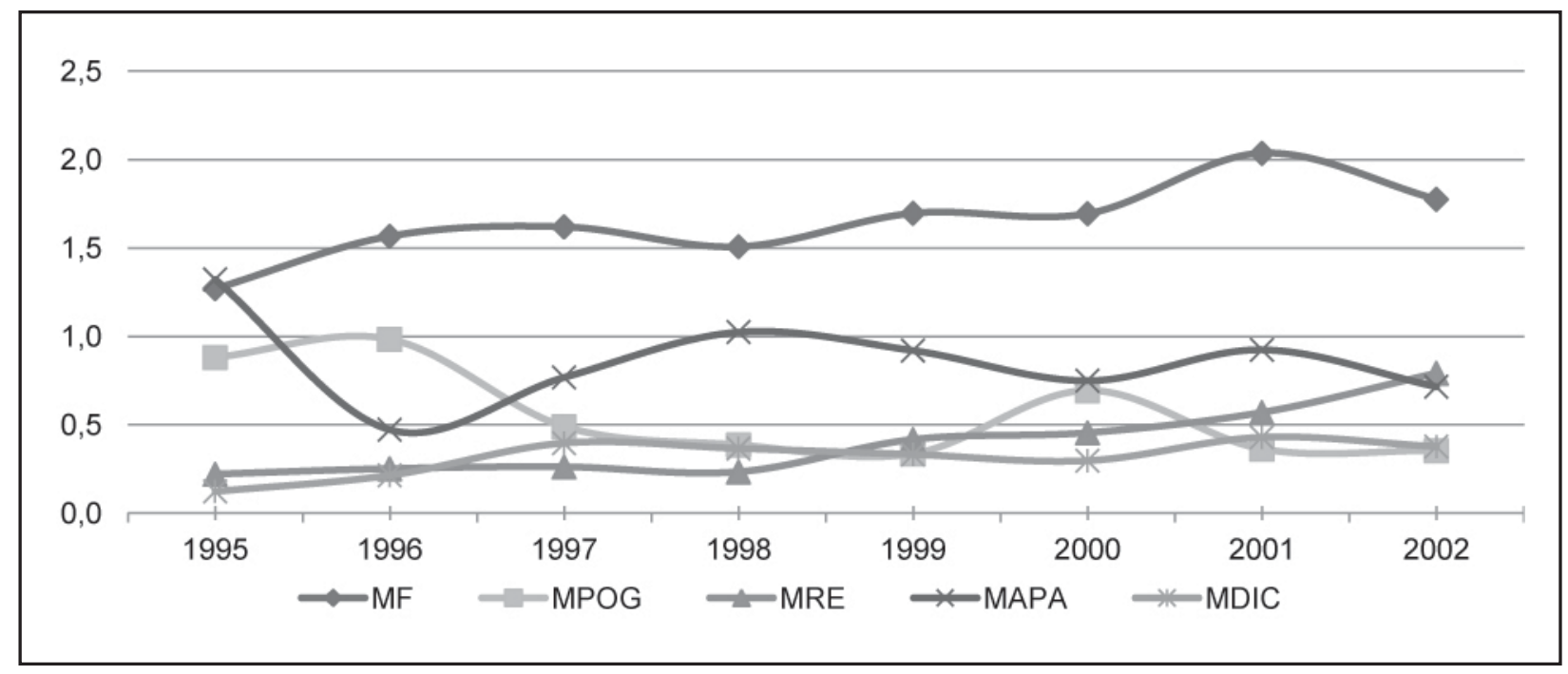

FONTE: Secretaria do Orçamento Federal do Ministério do Planejamento, Orçamento e Gestão.

Os gráficos 1, 2 e 3 mostram as despesas discricionárias ${ }^{14}$, as despesas com pessoal e o número de servidores de cada um dos cinco ministérios integrantes da Camex (fora a Casa Civil, que é o representante da presidência). A curva de gastos discricionários e com pessoal do Ministério da Fazenda é superior às dos outros. Os gastos do MDIC, por sua vez, não foram alterados em nenhum dos gráficos em 1999, mesmo que sua importância tenha sido frisada em discursos feitos pela presidência. No Gráfico 3, evidenciam-se as diferenças entre os ministérios no que se refere aos recursos humanos disponível. Mais uma vez, o Mistério da Fazenda é mais robusto do que qualquer um dos outros ministérios. Segundo os dados apresentados nos gráficos 1, 2 e 3, a criação do MDIC não teve consequência na relação entre os recursos disponibilizados ao ministério e os recursos disponibilizados aos outros.

GRÁFICO 2 - DESPESA DE PESSOAL DO PODER EXECUTIVO (R\$ BILHÕES CORRENTES)

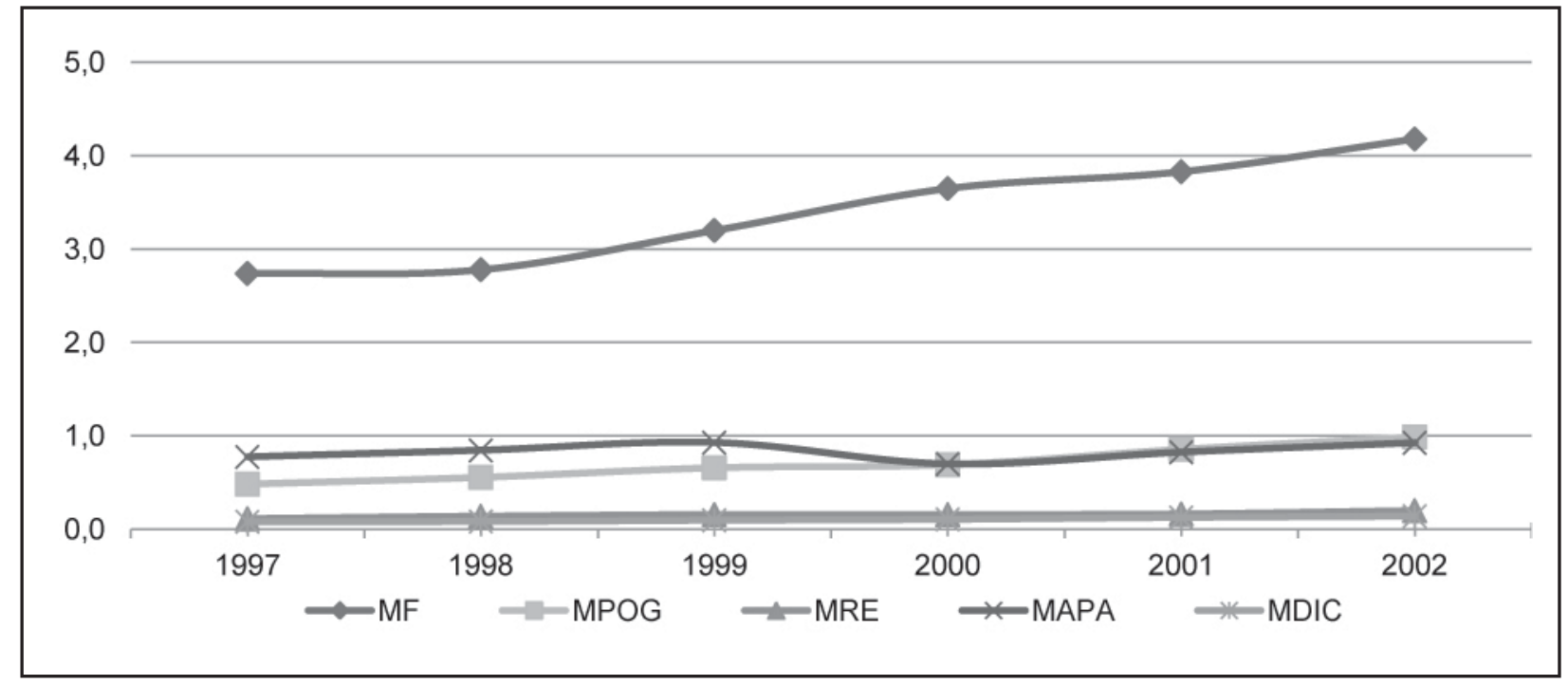

FONTE: Secretaria do Orçamento Federal do Ministério do Planejamento,Orçamento e Gestão.

14 Segundo a Secretaria do Orçamento Federal do Ministério do
Planejamento as despesas discricionárias são as que permitem
ao gestor público flexibilidade quanto ao estabelecimento do montante, assim como quanto à oportunidade da execução, e são efetivamente as que concorrem para produção de bens e serviços públicos. 
De posse das informações apresentadas nesta subseção, é possível concluir que no início do segundo mandato o principal conflito burocrático que afetou o comércio exterior foi o que se desenvolveu entre o MDIC e o Ministério da Fazenda. Este afetaria a institucionalidade da Camex, pois, além de ser um órgão recente e que passara por importante mudança, ela estava do lado mais fraco da contenda. De um lado, isso impediria que mudanças que afetassem os princípios da política econômica fazendária frutificassem. Por outro lado, seriam efetuados avanços em temas mais específicos à política comercial entre os anos de 1999 e 2002, ainda que houvesse oposição de algumas agências situadas dentro da estrutura administrativa do Ministério da Fazenda, a Receita Federal, conforme apresentamos nos próximos parágrafos.

GRÁFICO 3 - FORÇA DE TRABALHO POR MINISTÉRIOS (1000 SERVIDORES)

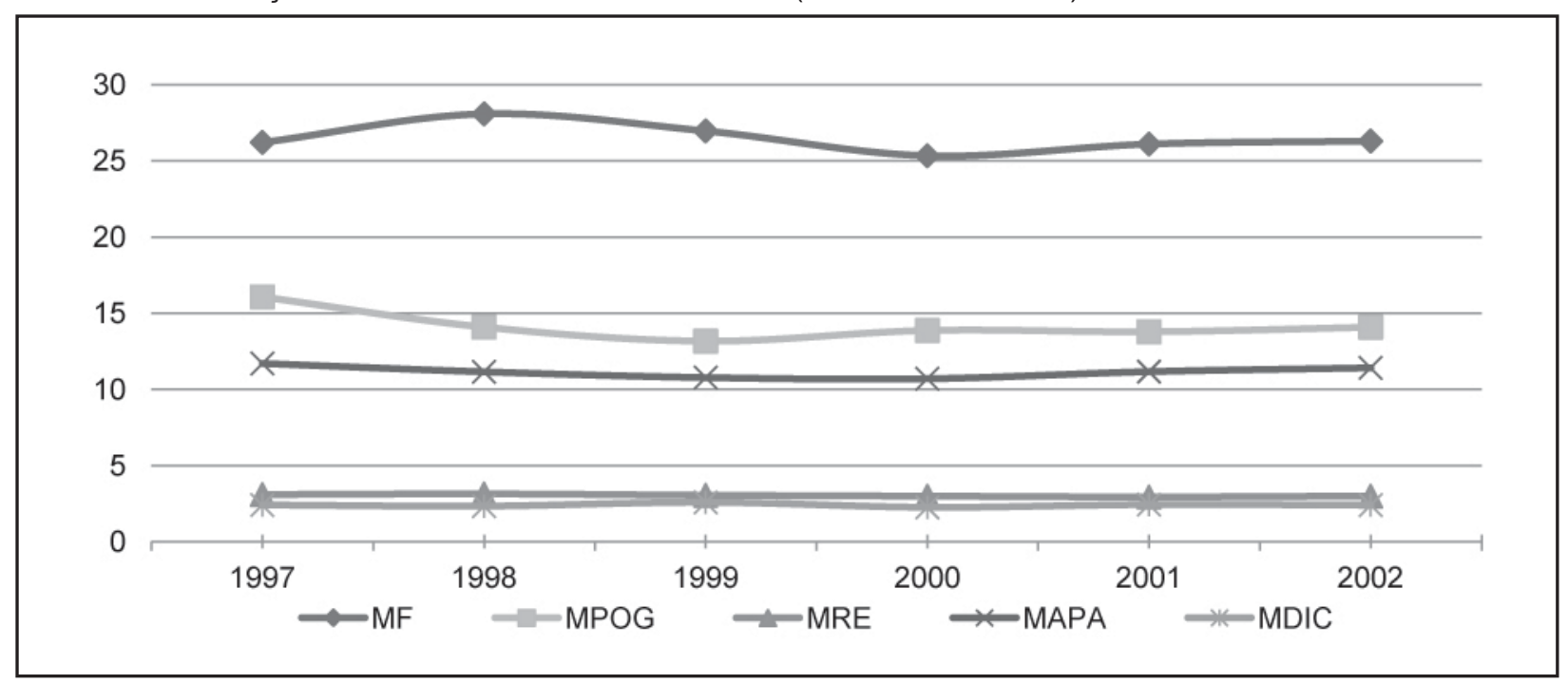

FONTE: Secretaria do Orçamento Federal do Ministério do Planejamento, Orçamento e Gestão.

\section{VI.4. Imposto de Importação e o fortalecimento da Camex como órgão do MDIC}

Apesar do redesenho institucional do comércio exterior ser, com a ida da Camex para o MDIC, uma indicação do fortalecimento do ministério, a queda de Carvalho demonstrou de modo contundente que a política comercial estava subordinada às necessidades e vicissitudes das políticas relacionadas com a estabilidade monetária. O passo seguinte na trama política foi o convite feito pelo próprio ministro Malan a Alcides Lopes Tápias, então presidente do Grupo Camargo Corrêa para assumir o cargo de ministro do desenvolvimento em setembro de 1999. Nessas condições políticas pouco propícias, os primeiros meses de Tápias à frente do MDIC não foram profícuos. Entre os motivos levantados, além dos limites impostos pelo Ministério da Fazenda, consta também a falta de controle por parte do ministro de dois dos principais cargos do MDIC: o BNDES e a Secretaria Executiva da Camex, ocupada pelo diplomata Botafogo Gonçalves.

José Botafogo Gonçalves fora nomeado pelo presidente e protagonizou uma situação bastante especial. Além de ser da Camex, também era diplomata, o que lhe permitia uma aproximação em alto nível com o MRE. Botafogo orientava sua gestão mais para o campo das relações internacionais do que para o campo da promoção e estímulo às exportações e reestruturação produtiva da indústria, que seria o novo foco que Tápias traria para o MDIC e para o comércio exterior. Ademais, conforme relatado por ex-secretário executivo e por ex-assessores especiais da Camex em entrevistas feitas com o autor, a gestão de Botafogo foi a última tentativa de estabelecer-se uma diferenciação, inevitável no médio prazo, entre Camex e MDIC. Dado suas habilidades diplomáticas e seu trânsito em outras instâncias fora do MDIC, Botafogo manteve um foco interministerial que seria inevitavelmente perdido por seus sucessores. Dessa maneira, ilustra-se que embora a Camex tenha ido para o MDIC em 1999, apenas em 2000, após a queda de Clóvis Carvalho e a ascensão de Alcides Tápias, é que o ministro do desenvolvimento indicou o secretário executivo da Camex.

O escolhido por Tápias foi Roberto Giannetti da Fonseca, um importante empresário envolvido com o comércio exterior brasileiro, vice-presidente da Funcex (Fundação Centro de Estudos do Comércio Exterior), 
com boas relações com a Fiesp (Federação das Indústrias do Estado de São Paulo) e o com o empresariado nacional, sobretudo paulista. Formavase, assim, uma liderança na administração do comércio exterior brasileiro cuja origem profissional estava nitidamente conectada ao empresariado paulista e distante das lideranças burocráticas e partidárias, representando um marco na evolução das relações entre MDIC e Camex.

O ministério a partir de então se tornou o principal representante da indústria e a Camex um instrumento para a adoção de políticas favoráveis ao setor produtivo nacional $^{15}$. Essa imbricação entre MDIC e empresariado foi a principal fortaleza do ministério. Sua clientela foi um dos grupos de interesse mais bem organizados e com maior capacidade de pressão sobre o governo.

Contudo apesar da indicação de Giannetti representar um fortalecimento de Tápias e do MDIC, a Camex ainda funcionava segundo a lógica de seu período na Casa Civil. Era um órgão consultivo e coordenativo, sem capacidade de deliberação e operacionalização de políticas. Dessa maneira, tudo o que era deliberado na Câmara tinha que ser executado isoladamente pelos ministérios. A Camex não tinha o poder de decidir de facto sobre o comércio exterior, apenas podia aconselhar os ministérios e solicitar que cumprissem com o que era combinado no Conselho de Ministros.

Esse desenho era pouco funcional à nova postura da Camex, subordinada ao MDIC e não mais à Casa Civil. A mera deliberação consultiva seria muito menos útil do que foi durante a sua fase no Palácio do Planalto, quando suas deliberações podiam ser executadas com o uso do poder de atração da presidência. Agora, as iniciativas deveriam ser promovidas por um ministério que não era o principal ator da administração pública, o que dificultava em muito fazer com que os outros membros cumprissem com aquilo que era acordado em sua plenária. Essa condição deteriorou-se ainda mais quando a Secretaria Executiva da Camex deixou de ser um cargo de nomeação da presidência e passou a ser indicada pelo próprio ministro do desenvolvimento. Esse modelo esdrúxulo que fora o vetor resultante do jogo de força entre aqueles que tentavam modificar a

15 Essa característica mostrou-se mais forte no governo Lula, quando dois famosos personagens do setor produtivo foram indicados para comandar o Ministério do Desenvolvimento. Os ministros Luiz Fernando Furlan e Miguel Jorge. O primeiro ocupou funções na Fiesp, além de ser presidente do conselho de administração do grupo Sadia, e o segundo construiu sua carreira profissional nas indústrias Autolatina e Volkswagen e no Banco Santander Banespa. política econômica e aqueles que desejavam mantê-la foi, ao longo do segundo mandato de Fernando Henrique Cardoso, um fator importante no processo de tensificação das relações burocráticas entre os envolvidos com o comércio exterior e com a política econômica de maneira mais ampla.

Durante a gestão de Tápias e de Giannetti, o principal conflito do MDIC e da Camex contra o Ministério da Fazenda foi em relação aos controles que a Secretaria da Receita Federal exercia sobre políticas aduaneiras e de incentivos às exportações. $\mathrm{O}$ objetivo era tornar a Camex o órgão responsável pelos instrumentos comerciais que influenciavam em curto e médio prazo o desempenho das empresas nacionais e também as políticas de defesa comercial e de promoção às exportações. Segundo a leitura do MDIC, a política aduaneira deveria ser considerada um instrumento regulatório de política industrial e não fiscal, devendo, portanto, ficar sob os seus auspícios e não sob o controle de um órgão orientado para a arrecadação. Tendo caráter regulatório, a transferência das tarifas de importação e exportação para a Camex não feriria o artigo 237 da Constituição.

Um fato relevante na passagem de Giannetti e de Tápias foi a diferente tonalidade da disputa política que travaram. A disputa contra o Ministério da Fazenda e em especial com a Receita Federal tinha como foco o fortalecimento de instrumentos específicos de política industrial e comercial e não mais a postura conservadora sobre toda a política econômica, que fora o foco das críticas da equipe econômica paralela e de Clóvis Carvalho. Nesse campo, a vitória dos monetaristas fora arrasadora. A ênfase na estabilização monetária era repetida como mantra por todo o governo. Tápias e Giannetti tinham um foco menos ambicioso. Pretendiam transformar a Camex em um órgão executor, retirando certos poderes de decisão do Ministério da Fazenda.

As alterações defendidas pelo MDIC e pela Camex tinham duplo significado: a diminuição do poder fazendário e o fortalecimento institucional da Câmara como órgão executor da política comercial. As divergências tomaram grandes proporções, sobretudo porque requeriam a redução de competências da Receita Federal e embora esta última fosse um órgão subministerial, ela era forte burocraticamente. Seu papel foi fundamental para o sucesso do Plano Real, quando adquiriu capital político para enfrentar um ministério desenhado para ser o grande ministério do segundo mandato.

Segundo informações veiculadas na imprensa, a Receita Federal resistia às investidas de Tápias e Giannetti, pois sua opinião era que os tributos possuíam 
várias funções, ora se enfatizando a arrecadação ora a regulação de mercados. Desta sorte, sendo papel exclusivo do Ministério da Fazenda, em especial da Receita Federal, a gestão e arrecadação de impostos e tributos, a transferência de competências sobre a gestão da política aduaneira e de instrumentos de incentivo às exportações para a Camex não seria constitucional (GIANNETTI QUER MAIS RECURSOS, 2000). Nesse embate, é necessário considerarmos o fato que o secretário da Receita Federal, Everardo Maciel, que ocupou o cargo durante toda era Fernando Henrique Cardoso, foi fortalecido durante o primeiro mandato devido às necessidades de se produzir aumentos da arrecadação em decorrência dos ajustes físcais oriundos do Plano Real, da política econômica desenhada pelo Ministério da Fazenda, dos ajustes feito com os estados da federação e com outros entes públicos que se financiavam com o imposto inflacionário. $\mathrm{O}$ que se somou à já louvável capacidade técnica e conhecimento da máquina pública dos funcionários da Receita Federal para expandir a arrecadação.

As taxas de crescimento da arrecadação por parte da Receita Federal entre 1992 e 2002 sempre esteve acima dos $10 \%$ e a evolução de sua arrecadação foi enorme, tendo crescido aproximadamente $187,5 \%$ entre 1995 e 2002. A Tabela 1 retrata essa evolução e demonstra que os impostos aduaneiros não eram os mais importantes da composição dos recursos arrecadados. Apenas cerca de 5\% da arrecadação era decorrente dos impostos de importação

Dito isso, fica claro que essa transferência de competências não afetaria o ajuste fiscal. A natureza da posição contrária da Receita às reformas justificase em termos da sua luta pela preservação de competências e de sua missão institucional. Algo natural em uma burocracia estruturada, conforme previsto na literatura sobre a política burocrática. É importante sublinhar também que a Secretaria da Receita Federal era um organismo com forte tessitura administrativa, possuindo uma das carreiras mais bem estruturadas dentro do Ministério da Fazenda.

Na opinião de Giannetti, junto com o Banco Central, era a carreira mais consolidada no Ministério da Fazenda. Uma demonstração da força da Receita Federal foi a permanência de Everardo Maciel, um funcionário de carreira, no cargo de chefia durante todo o governo. Dito isso, conclui-se que a Receita Federal tinha capital e força política para enfrentar o MDIC, sobretudo quando se tratasse de uma disputa burocrática que envolvesse ameaças às suas competências e missão ${ }^{16}$.

TABELA 1 - EVOLUÇÃO DAARRECADAÇÃO PELA RECEITA FEDERAL (R\$ MILHÕES CORRENTES)

\begin{tabular}{|c|c|c|c|c|c|c|c|c|c|c|c|}
\hline Arrecadação & 1992 & 1993 & 1994 & 1995 & 1996 & 1997 & 1998 & 1999 & 2000 & 2001 & 2002 \\
\hline $\begin{array}{l}\text { Impostos } \\
\text { aduaneiros }\end{array}$ & 1597 & 1734 & 2384 & 4911 & 4221 & 5138 & 6544 & 7916 & 8510 & 9087 & 7970 \\
\hline IPI & 8450 & 9770 & 10423 & 13635 & 15512 & 16833 & 16306 & 16503 & 18839 & 19456 & 19798 \\
\hline $\begin{array}{l}\text { Impostos } \\
\text { sobre renda }\end{array}$ & 13698 & 16396 & 18874 & 28969 & 33693 & 36524 & 45818 & 51516 & 56397 & 64908 & 85802 \\
\hline IPMF/CPMF & - & 252 & 4976 & 162 & 1 & 6909 & 8118 & 7956 & 14545 & 17197 & 20368 \\
\hline $\begin{array}{l}\text { FINSOCIAL/C } \\
\text { OFINS }\end{array}$ & 3590 & 5172 & 10718 & 15226 & 17892 & 19118 & 18745 & 32184 & 39903 & 46364 & 52266 \\
\hline PIS/PASEP & 4086 & 4616 & 5284 & 6122 & 7390 & 7590 & 7547 & 9835 & 10043 & 11396 & 12870 \\
\hline CSLL & 2292 & 3526 & 4499 & 5852 & 6598 & 7698 & 7704 & 7303 & 9278 & 9366 & 13363 \\
\hline $\begin{array}{l}\text { Outras } \\
\text { receitas }\end{array}$ & 2873 & 3532 & 5458 & 6063 & 6423 & 7252 & 6999 & 9343 & 9462 & 11024 & 20274 \\
\hline Total & 36585 & 45000 & 62616 & 80940 & 91728 & 107065 & 117782 & 142557 & 166976 & 188797 & 232711 \\
\hline
\end{tabular}

FONTE: Secretaria da Receita Federal do Brasil.

NOTA: Arrecadação de 1992 a 1994 (até junho) convertida pela URV média mensal.

A estrutura burocrática nessa instituição desenhase a partir das carreiras de Auditoria Fiscal e de Análise Tributária (AFRFB e ATRFB). A entrada na agência é semelhante à entrada no MRE, que é o ministério que possui a burocracia mais bem estruturada da administração federal. Após as provas do concurso, há um programa de formação profissional executado

\footnotetext{
16 Entrevista com Roberto Giannetti da Fonseca, realizada em 5 de maio de 2010 .
} 
pela Escola de Administração Fazendária. Concluída essa etapa, os aprovados são nomeados pelo coordenador geral de recursos humanos do Ministério da Fazenda. Após a abertura comercial foram realizados dezoito concursos para Auditoria Fiscal e Tributária da Receita Federal, seis no primeiro mandato de Fernando Henrique Cardoso e sete no segundo (Tabela 2). Já as informações sobre o número total de ingressantes nessas carreiras demonstram como a Receita Federal foi fortalecida no primeiro mandato de Fernando Henrique Cardoso: nada menos do que 46,1\% do total de ingressantes a partir de 1995 entraram nesse período (Tabela 3 ).
TABELA2 - NÚMERO DE CONCURSOS PARAARECEITA FEDERAL (AUDITORIA FISCAL E TRIBUTÁRIA)

\begin{tabular}{|cc|}
\hline Mandatos & $\begin{array}{c}\text { n. de concursos } \\
\text { realizados(AFRFB e ATRFB) }\end{array}$ \\
\hline $1990-1994$ & 1 \\
$1995-1998$ & 6 \\
$1999-2002$ & 7 \\
$2003-2010$ & 4 \\
\hline
\end{tabular}

FONTE: Secretaria da Receita Federal do Brasil.

TABELA 3 - INGRESSOS NA RECEITA FEDERAL DO BRASIL A PARTIR DE 1995 POR CONCURSO PÚBLICO

\begin{tabular}{|c|c|c|c|}
\hline \multirow{2}{*}{ Mandatos } & \multicolumn{2}{|c|}{ Carreiras } & \multirow{2}{*}{ Total (\%) } \\
\cline { 2 - 3 } & Auditor-Fiscal (AFRFB) & $\begin{array}{c}\text { Analista-Tributário } \\
\text { (ATRFB) }\end{array}$ & 46,1 \\
\hline $1995-1998$ & 1579 & 2142 & 7,3 \\
$1999-2002$ & 584 & 5 & 36,7 \\
$2003-2006$ & 976 & 1987 & 9,8 \\
\hline
\end{tabular}

FONTE: Boletim Estatístico de Pessoal da Secretaria de Recursos Humanos do Ministério do Planejamento, Orçamento e Gestão.

Do outro lado da contenda, embora o MDIC e a Camex não sejam órgãos com carreiras estruturadas que criem solidariedade e interesses comuns no longo prazo em torno da preservação e expansão de competências e recursos ${ }^{17}$, Tápias e Giannetti possuíam uma clientela importante e com vínculos muito fortes. Os próprios burocratas eram oriundos desse grupo de interesse. Giannetti tem uma longa história no comércio exterior, na Fiesp e na Funcex. Tápias foi vice-presidente do Bradesco, presidente da Febraban (Federação Brasileira de Bancos) entre 1991 e 1994, membro de diversos conselhos empresariais,

\footnotetext{
17 A principal carreira dentro do MDIC é a carreira de Analista de Comércio Exterior, criada somente em 1998 (Lei n. 9 620, de abril de 1998). Diferentemente das carreiras dos Ministérios da Fazenda e das Relações Exteriores, o MDIC não possui uma escola própria de formação de seus servidores. Após serem aprovados nas provas, os candidatos à analista de comércio exterior participam de cursos de formação da Escola Nacional de Administração (ENAP) do MPOG. Segundo dados fornecidos pela Associação dos Analistas do Comércio Exterior, existem hoje cerca de 240 Analistas de Comércio Exterior, a grande maioria lotada no Ministério do Desenvolvimento, que ingressaram na carreira por meio de quatro concursos públicos, realizados em 1998, 2000, 2002 e 2008.
}

presidente do Grupo Camargo Corrêa entre 1996 e 1999, presidente do conselho de administração da Usiminas e da São Paulo Alpargatas ${ }^{18}$.

Dessa forma, o conflito se articulava entre uma Receita Federal fortalecida, estruturada do ponto de vista burocrático, com uma liderança atipicamente forte e que não aceitava a redução de suas competências contra uma agência interministerial alocada num ministério setorial e mais fraco em relação a seu adversário, mas com fortes conexões com um dos grupos de interesse mais relevantes da sociedade - o empresariado paulista e exportador ${ }^{19}$.

\footnotetext{
18 Segundo o verbete sobre Alcides Lopes Tápias encontrado no banco de dados do Cpdoc-FGV (Centro de Pesquisa e Documentação de História Contemporânea do Brasil), a sua indicação para o MDIC teria levado em conta os fatos que Tápias era considerado independente em relação aos setores que divergiam sobre a política econômica de Fernando Henrique Cardoso (o debate entre monetaristas e desenvolvimentistas), era apartidário e tinha grande interlocução com os setores produtivos.

19 Reportagem da Folha de S. Paulo trata as relações entre Tápias e o empresariado da seguinte forma: "quem assistiu à posse do ministro do Desenvolvimento, Alcides Tápias, costuma dizer que boa parte do PIB brasileiro esteve presente. Essa é
} 
Em janeiro de 2001, após um longo embate, Tápias e Giannetti obtiveram duas importantes vitórias. A Camex passou a tomar decisões obrigatórias por meio de "Resolução", superando o caráter consultivo que limitara o seu raio de ação. Assim, além de apenas estabelecer diretrizes, a Camex poderia tomar decisões obrigatórias, transformando-se em um órgão colegiado deliberativo semelhante ao Conselho Monetário Nacional. As "Resoluções" deviam ser tomadas em consenso pelos ministros da Casa Civil, do Desenvolvimento, da Fazenda, da Agricultura e Relações Exteriores. A Camex tornou-se, além de uma instância interministerial de interlocução, um órgão "com dentes".

A outra vitória foi ganhar competência para decidir, por meio das resoluções, as alíquotas dos impostos de importação e exportação, podendo impor também medidas de defesa comercial ${ }^{20}$. Antes, os impostos de importação e exportação eram decididos pelo Ministério da Fazenda e as medidas de defesa eram tomadas em ato conjunto por esse ministério e pelo Ministério do Desenvolvimento. O Decreto n. 3756 também criou o Comitê Executivo da Camex, composto pelos secretários executivos dos ministérios que a integram, mais o secretário de comércio exterior do MDIC, o secretário da Receita Federal, o secretário de Assuntos Internacionais do Ministério da Fazenda e o diretor de Assuntos Internacionais do Banco Central. Esse comitê apoiaria o Conselho de Ministros, manifestando-se sobre as matérias que seriam decididas nesse conselho. De maneira curiosa, em junho de 2001, justamente durante sua melhor fase, quando conseguiu obter suas principais vitórias, o ministro Tápias pediu demissão (CANTANHÊDE, 2001). De acordo com as impressões de Giannetti, a saída de Tápias foi motivada mais

a força do ministro, que na semana passada voltou a se desentender com o Ministério da Fazenda. [...] Tápias continua com o firme apoio dos industriais, sobretudo os paulistas. Segundo a assessoria de imprensa da Fiesp, o presidente da organização, Horacio Lafer Piva, claramente apoia Tápias em sua disputa com o secretário da Receita Federal, Everardo Maciel. O presidente da CNI (Confederação Nacional da Indústria), deputado Carlos Eduardo Moreira Ferreira (PFL-SP), diz que o ministro é um bom interlocutor da indústria no governo. A chegada de Roberto Giannetti da Fonseca para presidir a Camex (Câmara de Comércio Exterior), a convite de Tápias, só reforçou a relação do Desenvolvimento com o empresariado paulista e com os exportadores. Na iniciativa privada, Giannetti sempre ocupou cargos voltados para o comércio exterior" (CANTANHÊDE, 2000).

20 Medida Provisória n. 2 113/27, que tratou das competências da Camex em decidir sobre a política aduaneira e o Decreto n. 3 756, de fevereiro de 2001, que deu o poder de decisão por meio de resolução a Camex. por questões pessoais e por um desprezo pela disputa por poder entre as burocracias, do que pelo enfraquecimento do MDIC ${ }^{21}$.

\section{VI.5. Redução do conflito e diminuição do escopo da Camex e do MDIC}

O sucessor de Alcides Tápias foi o ministro e embaixador Sérgio Amaral, que tomou posse em agosto de 2001. Seus planos para o ministério também se focaram no comércio exterior e na política de promoção às exportações. A política econômica monetarista do Ministério da Fazenda, baseada na estabilidade e equilíbrio macroeconômico, tinha se tornado a principal prioridade do governo. Nenhuma burocracia que se predispusesse a enfrentá-la sairia vitoriosa da disputa. No governo Cardoso, ficou claro o seguinte padrão: todos que ensaiaram uma argumentação mais crítica à política econômica realizada pelo Ministério da Fazenda foram enfraquecidos e derrotados.

O próprio Ministério do Desenvolvimento, que fora criado para contrapor-se ao Ministério da Fazenda, sofreu as principais conseqüências disso. Nos quatro anos do segundo mandato de Fernando Henrique Cardoso, nada menos do que quatro diferentes ministros passaram pelo ministério, sem contar o seu mentor, Luis Carlos Mendonça de Barros, que caiu antes de assumir e nem mesmo chegou a ocupar a cadeira que desenhou. O único espaço político que restava era para a discussão de questões mais específicas do comércio exterior, que não afetassem a política econômica monetarista realizada pelo Ministério da Fazenda, justamente o caminho adotado pelo MDIC e pela Camex na gestão de Tápias e de Giannetti. No Quadro 2, apresentamos quais foram as liderança burocráticas analisadas ao longo do estudo, de modo a salientar a instabilidade vigente no MDIC e na própria Camex ao longo do governo Cardoso.

21 Entrevista com Roberto Giannetti da Fonseca, realizada em 5 de maio de 2010. 
QUADRO 2 - MINISTROS DAFAZENDA E DO DESENVOLVIMENTO E SECRETÁRIOS DA RECEITA FEDERAL E DA CAMEX DURANTE O GOVERNO CARDOSO

\begin{tabular}{|c|c|c|c|}
\hline $\begin{array}{l}\text { Ministros } \\
\text { da Fazenda }\end{array}$ & $\begin{array}{l}\text { Secretários da } \\
\text { Receita Federal }\end{array}$ & $\begin{array}{l}\text { Ministros do Desenvolvimento } \\
\text { (MICT e MDIC) }\end{array}$ & Secretários Executivos da Camex \\
\hline \multirow{6}{*}{$\begin{array}{l}\text { Pedro Malan } \\
(1995-2002)\end{array}$} & \multirow{6}{*}{$\begin{array}{l}\text { Everardo Maciel } \\
(1995-2002)\end{array}$} & $\begin{array}{l}\text { Dorothea Fonseca Werneck } \\
\qquad(1995-1996)\end{array}$ & $\begin{array}{l}\text { Sérgio Amaral } \\
\text { (1995) }\end{array}$ \\
\hline & & $\begin{array}{l}\text { Francisco Neves Dornelles } \\
\qquad(1996-1998)\end{array}$ & $\begin{array}{c}\text { José Tavarez de Araujo } \\
(1995-1996)\end{array}$ \\
\hline & & José Botafogo Gonçalves (1998) & $\begin{array}{c}\text { José Frederico Alvarez } \\
\text { (1996-1998) }\end{array}$ \\
\hline & & $\begin{array}{l}\text { Celso Lafer } \\
\text { (1999) }\end{array}$ & $\begin{array}{l}\text { José Roberto Mendonça de Barros } \\
\qquad(1998)\end{array}$ \\
\hline & & $\begin{array}{l}\text { Clóvis de Barros Carvalho } \\
\text { (1999) }\end{array}$ & $\begin{array}{l}\text { José Botafogo Gonçalves } \\
(1999-2000)\end{array}$ \\
\hline & & $\begin{array}{l}\text { Alcides Tápias (1999-2001) } \\
\text { Sérgio Amaral (2001-2002) }\end{array}$ & $\begin{array}{l}\text { Roberto Giannetti da Fonseca } \\
\qquad(2000-2002)\end{array}$ \\
\hline
\end{tabular}

FONTE: O autor.

O último ministro do desenvolvimento do governo Cardoso, o embaixador Sérgio Amaral, foi muito menos belicoso que o seu antecessor ${ }^{22}$, assemelhando-se por conta disso ao período de Lafer. O conflito com a Receita Federal já se encerrara favorecendo a Camex, que agora era competente para decidir sobre impostos de importação, exportação e defesa comercial. De acordo com relatos, a indicação de Amaral fora feita para reduzir a estridência do conflito entre o Ministério do Desenvolvimento e o Ministério da Fazenda. Em sua gestão houve uma diminuição das pretensões e também uma redução do escopo das atividades e da capacidade propor e formular políticas que afrontassem as necessidades fiscais do Ministério da Fazenda por parte do MDIC. Amaral fora membro da equipe econômica que formulou o Plano Real, quando ocupou o cargo de chefe do gabinete do Ministro da Fazenda em 1994, o que lhe permitia melhor trânsito com a burocracia fazendária, uma vez que não era visto como alguém incompatível com as diretrizes da política econômica focada em instrumentos horizontais da equipe liderada por Malan.

Em outubro de 2001, dois meses após a posse de Sérgio Amaral, a Camex sofreu nova reforma em sua estrutura institucional, com a promulgação do Decreto n. 3 981. As principais mudanças foram a transformação do Comitê Executivo (Comex) no Comitê de Gestão da Camex, conhecido como Gecex, que trabalharia em

22 Em entrevista com funcionário do MDIC, foi-nos revelado que o período Amaral foi um momento de acomodação após os inúmeros conflitos e rusgas criadas no período de Tápias e Giannetti. conjunto com o Conselho de Minis-tros; a reinclusão do Ministério do Planejamento nesse conselho e a alteração do escopo das funções exercidas pela Camex como fórum coordenador da política comercial.

De acordo com um ex-secretário executivo da Camex, o Gecex foi criado para solucionar o problema gerado pela regra do consenso dentro do Conselho de Ministros. Quando não se era possível alcançar o consenso, a questão tinha de ser levada à presidência. No entanto, o presidente não era afeito a tomar decisões em matéria de política comercial, pois não se considerava suficientemente conhecedor da matéria. Segundo o relato, o presidente queria apenas exercer o papel de consultor e conselheiro e não de tomador de decisões. Dessa maneira, era um grande constrangimento levar uma questão sobre a política comercial para a decisão da presidência. Dessa forma, o Gecex seria um novo órgão filtrador das questões mais controversas, servindo como foro para as discus-sões entre os secretários executivos dos ministérios envolvidos com a Camex. O que era tratado no Gecex e não obtinha o consenso, acabava por não ser passado ao Conselho de Ministros. No entanto, isso não quer dizer que as grandes questões eram decididas no Gecex. Muitas questões importantes foram deixadas de lado quando os secretários executivos não chegarem a entendimentos mínimos sobre qual decisão deveria ser tomada (FERNANDES, 2011b).

Outro ponto fundamental dessa terceira e menor reforma está na mudança do escopo das funções da Camex. Deixou de ser um organismo formulador, pois seus objetivos tornaram-se apenas a adoção, a implementação e a coordenação das políticas de 
comércio exterior ${ }^{23}$. Após a transferência da Camex para o MDIC e de seu fortalecimento em fevereiro de 2001, ela perdeu a competência de formular a política de comércio exterior (RAMOS, 2008) ${ }^{24}$.

Essa alteração demonstra uma perda de status simbólico da Camex dentro da administração federal. A redução de sua capacidade de formulação foi resultado da adequação do MDIC aos limites da política econômica monetarista ao longo do segundo mandato de Fernando Henrique Cardoso, o que demonstra a disfuncionalidade que a transferência da Camex para um ministério setorial trouxe para a sua capacidade de coordenação interministerial. Isso porque a Câmara deixara de ser um órgão supraministerial, tornandose, na prática, uma agência de coordenação intraministerial, de pouco alcance, ao ser subordinada ao Ministério do Desenvolvimento, que não é o mais forte dentro da administração federal.

Na Figura 3 apresentamos a estrutura institucional da política comercial no final do segundo mandato do governo Cardoso, demonstrando a posição do Conselho de Ministros da Camex dentro do governo federal. Como conseqüência dessa nova institucionali-dade, apuramos que durante o governo Lula os ministros deixaram de freqüentar a plenária principal, sendo representados na maior parte das vezes por seus secretários executivos. Dessa forma, a Camex acabou ao longo do tempo especializando-se apenas na operacionalização cotidiana de assuntos tópicos, que embora sejam importantes no curto prazo, não orientam a formação de uma estratégia comercial de longo alcance (FERNANDES, 2011b).

Embora a transferência ministerial da Camex tenha sido importante para o fortalecimento do MDIC, isso restringiu a capacidade de coordenação que o seu projeto inicial buscava proporcionar para o sistema de comércio exterior como um todo. A Câmara tornou-se parte e refém de um dos interessados nas disputas: o empresariado representado dentro do MDIC. Além disso, perdeu o poder de convocação que a proximidade com a presidência lhe conferia. Para Giannetti, que foi o primeiro secretário executivo da Camex indicado por um ministro do desenvolvimento: "Na prática o que aconteceu é que a Camex passou a ser na verdade, quase um órgão assessor do Ministério do Desenvolvimento e foi totalmente desfigurada de sua missão original. Ela saiu da Presidência da República para ser subordinada ao Ministro do Desenvolvimento, da Indústria e do Comércio, onde o presidente da Camex não é o Presidente da República, mas o Ministro do Desenvolvimento, por delegação do Presidente da República; portanto, o Ministério do Desenvolvimento é que articula com os outros Ministérios a política de comércio exterior, junto com o secretário executivo da Camex [...] mas ele (o MDIC) é parte conflitante, então fica difícil ser também coordenador. É a mesma coisa se você colocasse num time de futebol um jogador para ser o técnico [...]" (Giannetti apud RAMOS, 2008).

FIGURA 3 - APARATO INSTITUCIONAL DA POLÍTICA COMERCIAL NO SEGUNDO MANDATO DO GOVERNO FERNANDO HENRIQUE CARDOSO

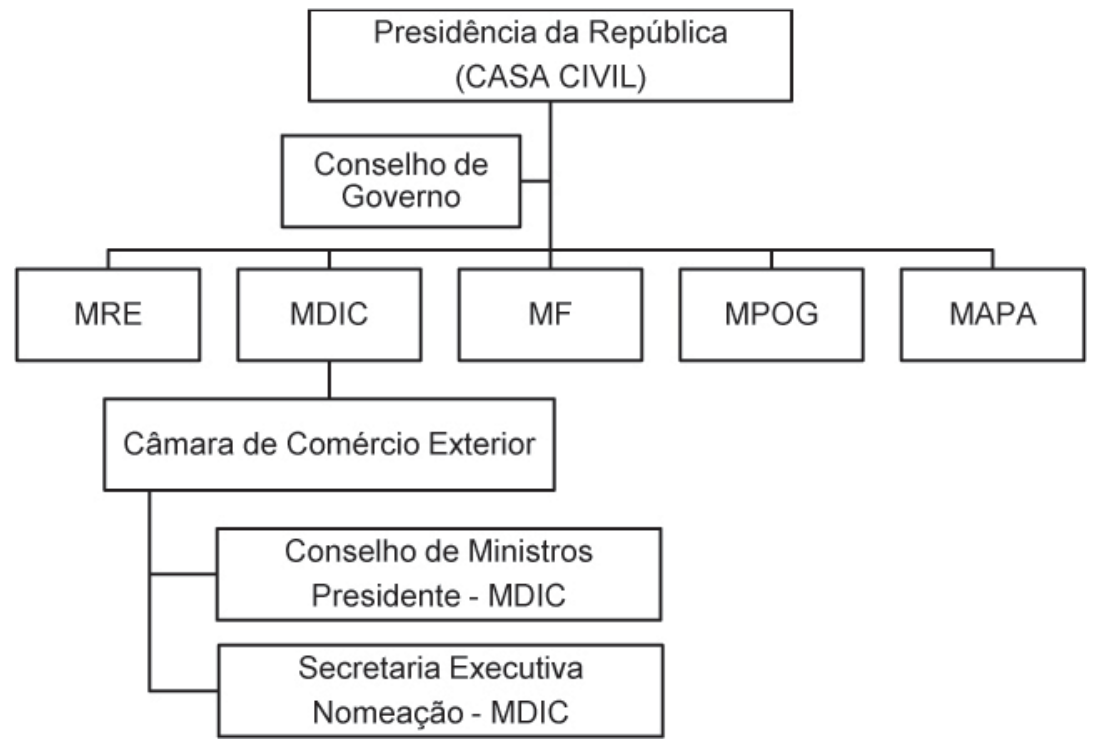

FONTE: O autor, a partir do Decreto n. 3 981, de 24 de outubro de 2001.

23 Artigo n. 1 do Decreto n. 3 981, de 24 de outubro de 2001.

24 Essa função foi posteriormente restabelecida no início do governo Lula. Alguns membros da Camex, que serviram nessa época, revelaram-nos que essa mudança não teve impacto no cotidiano administrativo da Câmara. 
Ramos (idem) inferiu, a partir de entrevistas com atores e observadores da política comercial brasileira, que a supressão da atribuição de formular a política de comércio exterior teria sido resultante do jogo de pressões políticas e de poder inerente ao sistema político brasileiro que, por sua vez, obrigava que algumas concessões na administração pública fossem realizadas devido a débitos da coalizão política ou de interesses organizacionais envolvidos. Uma das hipóteses aventadas por Ramos (idem) é que a possibilidade de criação de um super ministério, veiculada durante as gestões de José Botafogo Gonçalves e de José Mendonça de Barros na Secretaria Executiva da Camex, já teria sido suficientemente assustadora para os ministérios, de modo que o fortalecimento do seu colegiado foi constantemente combatido. No entanto, a partir das informações que obtivemos ao longo de nossa pesquisa, a hipótese é equivocada, uma vez que os maiores conflitos entre o Ministério da Fazenda e o MDIC foram amenizados durante a gestão de Sérgio Amaral.

A redução do escopo da Camex não deve ser atribuída à possibilidade de criação de um super ministério, mas sim ao resultado não esperado de conflitos entre burocracias. Essa mudança teria sido fruto de um processo de acomodação das ambições do Ministério da Fazenda e do MDIC. Em resumo, o resultado do enfraquecimento da Camex foi o vetor final da interação entre os atores que estiveram envolvidos no conflito burocrático mais estridente ocorrido durante o governo Cardoso, como previsto no modelo teórico.

\section{CONCLUSÕES}

Nesta última e conclusiva seção são reunidos e resumidos os achados empíricos. Após, são comparados com as proposições teóricas, esclarecendo o quanto estas esclarecem o processo de reformas da institucionalidade da política comercial brasileira. Por fim, concluímos os argumentos que encadeiam a análise sobre a evolução institucional do arcabouço de coordenação da política comercial ao longo do governo Cardoso.

A evolução institucional do arcabouço de coordenação da política comercial no período estudado não foi caracterizada unicamente por processos burocráticos conflituosos. Apesar da natureza do comércio exterior ser complexa e de caráter multifacetado, envolvendo diferentes ministérios, em uma razoável gama de assuntos, durante o primeiro mandato de Fernando Henrique Cardoso o processo de criação do modelo institucional da Camex foi realizado em um ambiente de razoável concordância burocrática. A decisão adotada era aceita por todos os participantes e não reduzia nenhuma competência burocrática dos ministérios envolvidos. No entanto, durante o segundo mandato, o conflito permeou de maneira contundente as decisões institucionais. Em um período de quatro anos, foram feitas três reformas relevantes e em sentidos distintos sobre a institucionalidade da Camex. Neste momento, os conflitos burocráticos tiveram origem na busca por maior influência dos burocratas envolvidos com o processo decisório do plano de estabilização e da política econômica do governo.

De fato, o processo de divisão e de conflito dentro da equipe econômica tomou corpo com o encerramento da primeira fase do Plano Real e a aproximação do segundo mandato, atravessando várias instituições e dividindo os auxiliares econômicos do presidente entre desenvolvimentistas, cujos principais líderes formaram a equipe econômica paralela em 1998, e os monetaristas, abrigados no Ministério da Fazenda e no Banco Central, que comandaram as diretrizes da política econômica ao longo de todo governo Cardoso.

A primeira dessas reformas, a transferência da Camex para o MDIC, foi realizada com o objetivo de fortalecer esse ministério como um ator importante dentro da seara da política econômica do governo. Essa mudança foi conseqüência dos projetos desenhados pela equipe paralela, como a criação de um ministério mais robusto, incorporando o BNDES e a Camex, desejando reduzir a importância do Ministério da Fazenda. Contudo, ao passo que a Camex fortaleceu o MDIC, a sua saída da Casa Civil, rebaixou seu status simbólico dentro da estrutura administrativa federal.

A segunda reforma, a obtenção de competências para a Camex tomar decisões obrigatórias por meio de "Resolução" em alguns temas importantes como a política de defesa comercial e sobre as alíquotas da política aduaneira, por sua vez, teve como objetivo fortalecer a própria instituição, que teve sua funcionalidade coordenativa limitada ao perder o poder de convocação existente na Casa Civil. Essa nova Camex, menos abrangente e mais afinada com o MDIC, abandonava completamente o perfil de think thank público obtido no primeiro mandato, tornando-se apenas mais uma agência executora de políticas específicas entre o vasto rol de funções de comércio exterior.

No que toca aos interesses daqueles que a dirigiam naquele momento, essa reforma foi uma grande vitória, pois, mesmo que as discussões tenham se afastado das críticas às balizas fundamentais da condução da política econômica, o controle das alíquotas de importação e exportação e das políticas de defesa aumentaram o leque de medidas disponíveis ao MDIC 
para atender a sua clientela principal, o empresariado. Salientamos que o sucesso da reforma nesse sentido só foi possível devido ao fato que as críticas de Tápias e Giannetti voltaram-se rotineiramente à gestão feita por Everardo Maciel na Receita Federal e não mais ao alto comando do Ministério da Fazenda. Para Tápias, a Receita seria pouco flexível e despreocupada das conseqüências que o sistema tributário trazia para o setor produtivo. Isso posto, fica claro que o MDIC não mais criticava a condução geral da política macroeconômica, mas sim instrumentos específicos de interesse do empresariado. No caso específico, as alíquotas de importação e exportação e medidas de defesa comercial.

Por fim, a terceira e última reforma da Camex foi a perda de sua competência de formulação da própria política para qual foi criada, evidenciando a disfuncionalidade do seu desenho institucional. Essa reforma teve como intuito reduzir o escopo da Camex, já durante a gestão de Sérgio Amaral, que fora nomeado com a finalidade de abrandar os atritos que haviam se avolumado de modo bastante agudo entre os membros do Ministério da Fazenda e do MDIC.

De forma resumida, a partir da criação da Camex como órgão eminentemente consultivo e de discussão, a Câmara ganhou força e espaço na coordenação do comércio exterior. Mas esses desenvolvimentos foram minados com a transferência ministerial, que culminou com a reforma de outubro de 2001, que restringiu o escopo de suas funções ao eliminar a competência de formulação, tornando-a apenas um veículo de implementação. Isso foi uma demonstração cabal da disfuncionalidade que sua transferência para o MDIC trouxe para sua capacidade de impor-se como lócus de coordenação supraministerial. A tentativa de fortalecer o corpo opositor da política macroeconômica do Ministério da Fazenda dentro do próprio governo teve como conseqüência a redução da capacidade de coordenação da política comercial.

Os dados qualitativos e quantitativos levantados demonstram, portanto, que a política comercial foi conflituosa no segundo mandato de Cardoso. Esses conflitos foram externalidades das disputas que envolveram a política econômica como um todo. No campo da política econômica, o resultado foi a supremacia da vontade do Ministério da Fazenda, sobretudo no que se refere aos assuntos que impactaram a estabilidade econômica (o principal ativo político do governo Cardoso). O espaço para a ação dos membros do MDIC só foi menos constrangido no que se refere aos instrumentos específicos à política comercial, possibilitando alguns pequenos sucessos para os atores desenvolvimentistas, como, por exemplo, os ganhos de competência da Camex sobre as alíquotas de importação e exportação e sobre as medidas de defesa comercial, além da capacidade de emitir decisões obrigatórias por meio de "Resoluções".

Retomando os conceitos apresentados na seção 3, embora tenha havido, na política macroeconômica, uma clara imposição burocrática por parte de uma burocracia específica, poderosa e apoiada de maneira inequívoca pela presidência - o Ministério da Fazenda -, as disputas sobre temas da política comercial foram mais equilibradas. Houve momentos em que o MDIC e a própria Camex conseguiram preponderar e outros em que o Ministério da Fazenda impôs-se, uma vez que nessa seara os recursos burocráticos disponíveis a cada um dos atores envolvidos eram menos desiguais, caracterizando o conflito burocrático.

É importante salientar que, em conformidade com o quadro teórico, essa dinâmica só foi possível devido à não interferência presidencial na política comercial, cuja atuação no caso analisado foi praticamente nula. O presidente Fernando Henrique Cardoso só interferiu nessas disputas quando o conflito reverberou na estratégia de estabilização econômica, como, por exemplo, no caso da demissão de Clóvis Carvalho em 1999, e não quando disputas sobre especificidades das decisões comerciais foram postas na mesa, incluindo aqui as reformas sobre o quadro de coordenação. A política comercial não era e não foi em nenhum momento uma das prioridades políticas da presidência.

Além disso, é evidente a existência de interesses divergentes entre os atores envolvidos em nosso estudo de caso. Enquanto, no Ministério da Fazenda, defendiam-se políticas horizontais e a proteção ao ajuste fiscal, no Ministério do Desenvolvimento defendia-se a necessidade da adoção de políticas setoriais que estimulassem o crescimento econômico.

Dessa maneira, a variável chave a ser compreendida é o poder de cada uma dessas agências, traduzido no conjunto de recursos disponíveis aos dois grupos. Conforme demonstrado na seção anterior, o Ministério da Fazenda é o ministério que possui mais recursos dentro da administração federal, enquanto o MDIC possui o apoio de uma clientela bastante influente: o empresariado. Essa configuração de poder permite ao MDIC pressionar o Ministério da Fazenda, sobretudo em temas específicos e de interesse do empresariado, e que não afetam os objetivos da política econômica como um todo. Foi justamente essa dinâmica que imperou dentro do governo Cardoso, principalmente no seu segundo mandato, quando atores envolvidos com essas políticas divergiram sobre quais seriam as consequiências de políticas setoriais mais incisivas para a estabilidade macroeconômica. 
Diante do conjunto de elementos, concluímos, enfim, que o projeto de uma Câmara que coordenasse o comércio exterior em alto nível dentro de um ministério ordinário e setorial como o MDIC não foi o projeto idealizado por nenhum dos atores interessados em ampliar a capacidade de coordenação e interlocução do comércio exterior brasileiro, mas sim fruto de um processo decisório conflituoso, marcado por diferentes arranjos e equilíbrios políticos momentâneos e instáveis, como preconizado no modelo teórico apresentado.

A presença e consolidação da Camex no MDIC foi, portanto, fruto de um amplo e complexo processo de intermediação de interesses entre o Ministério da Fazenda e os ministérios defensores de ações mais incisivas que estimulassem seletivamente a produção nacional. As reformas decorrentes desse intrincado jogo de barganha, acomodação e compromisso entre os atores situados nas posições-chave do poder Executivo, que nem sempre possuíram objetivos e métodos convergentes, teve como consequiência a formação de equilíbrios instáveis e suscetíveis a alterações decorrentes dos embates entre os ministérios, o que resultou em um formato institucional que não era o defendido por nenhum dos atores envolvidos com a política comercial brasileira.

Como nota final, apesar do quadro teórico ter sido parcimonioso e suficiente para esclarecer a dinâmica da política comercial no governo Cardoso, é importante estarmos atentos para o fato de que as variáveis analisadas são condições suficientes para a compreensão de processos decisórios dentro do poder Executivo pouco afetados por variáveis externas a esse poder, como, por exemplo, a ação independente de grupos de interesse ou mesmo o papel exercido pelo poder Judiciário e/ou o Legislativo. Para a incorporação desses novos atores, é necessário o desenvolvimento de ferramentais teóricos que possam reunir a literatura que não trata do poder Executivo como um ator monolítico com aquelas que versam sobre as relações Executivo-Legislativo e sobre o papel do poder Judiciário nos sistemas políticos contemporâneos.

Ivan Filipe de Almeida Lopes Fernandes (ivan.fernandes@usp.br) é Doutorando em Ciência Política pela Universidade de São Paulo (USP).

\section{REFERÊNCIAS BIBLIOGRÁFICAS}

ALLISON, G. 1969. Conceptual Models and the Cuban Missile Crises. America Political Science Review, Los Angeles, v. 63, n. 3, p. 689-718, Sep. Disponível em: http://www3.nccu.edu.tw/ lorenzo/ Allison\%20Conceptual\%20Models.pdf. Acesso em: 22.abr.2013.

1971. Essence of Decision: Explaining the Cuban Missile Crisis. Boston: Little Brown.

LLISON, G. \& HALPERIN, M. 1972. Bureaucratic Politics: A paradigm and some policy Implications. World Politics, Baltimore, v. 24, número suplementar "Theory and Policy in International Relations", p. 40-79, Spring. Disponível em: http://www. polsci.wvu.edu/faculty/hauser/PS293/Allison HalperinBureaucraticPolWP1972.pdf. Acesso em: 23.abr.2013.

ALLISON, G. \& ZELIKOW, P. 1999. Essence of Decision: Explaining the Cuban Missile Crisis. $2^{\text {a }}$ ed. New York: Longman.

BARBOSA, R. 1994. Uma nova estrutura para o comércio exterior. Revista Brasileira de Comércio Exterior, Rio de Janeiro, n. 41, out.-dez.

BREWER, G. 2008. Bureaucratic Politics. In: RABIN, J. \& WACHLUS, A. (eds.). Encyclopedia of
Public Administration and Public Policy. $2^{\mathrm{a}}$ ed. V. 1. Boca Raton: CRC.

CANTANHÊDE, E. 2000. A República da Fazenda está prestes a fazer mais uma vítima. Folha de S. Paulo, 21.nov.

2001. Nenhum ministro esquentaria a cadeira no Desenvolvimento. Folha de S. Paulo, 25.jul.

CARDOSO, F. H. 1974. Autoritarismo e democratização. Paz e Terra: Rio de Janeiro.

1994. Mãos a obra Brasil: proposta de governo. Rio de Janeiro: Centro Edelstein de Pesquisas Sociais. Disponível em: http://pt.scribd.com/doc/ 54397409/CARDOSO-Maos-a-obra-pdf-07-102008-18-20-37. Acesso em: 25.abr.2013.

1999. Declaração à imprensa por ocasião da apresentação de novos ministros, realizada no Palácio do Planalto, Brasília, em 16 de julho de 1999. Programa de rádio "Palavra do Presidente".

2006. A arte da política. A história que vivi. $2^{\mathrm{a}}$ ed. Rio de Janeiro: Civilização Brasileira.

Sem data. Palavra do Presidente. Coletânea de Discursos. 
DOWNS, A. 1966. Inside Bureaucracy. The Rand Corporation. Boston: Little Brown.

DUNLEAVY, P. 1991. Democracy Bureaucracy \& Public Choice. Economic Explanations in Political Science. Sussex: Harvester.

FERNANDES, I. 2011a. Interesses Organizados na Política Comercial Brasileira: da Era CACEX às Negociações Internacionais. Leviathan, n. 2, p. 135. Disponível em: http://www.fflch.usp.br/dcp/ leviathan/index.php/leviathan/article/view/41/pdf. Acesso em: 25.abr.2013.

2011b. Burocracia e política. A construção institucional da política comercial brasileira. São Paulo: Biblioteca 24 Horas.

FIGUEIREDO, A. 2010. Executivo e Burocracia. In: MARTINS, C. \& LESSA, R. (orgs.). Ciência Política. Col. "Horizontes das Ciências Sociais no Brasil”. São Paulo:Barcarolla.

FREEDMAN, L. 1976. Logic, Politics and Foreign Policy Process: A Critique of Bureaucratic Politics Model. Journal of International Affairs, New York, v. 52, n. 3, p. 434-449, July.

FRANÇA, W. 1997. Comércio exterior não terá ministério. Folha de S. Paulo, 2.fev.

FRIEDLANDER, D. 2000. Everardo fala sobre pacote e irrita Tápias. Folha de S. Paulo, 18.nov.

GOODIN, R. 1975. The Logic of Bureaucratic Back Scratching. Public Choice, New York, v. 24, p. 53-67, Spring.

HALPERIN, M. 1974. Bureaucratic Politics and Foreign Policy. Washington (DC): Brookings.

HILSMAN, R. 1959. The Foreign Policy Consensus: An interim report. Journal of Conflict Resolution, Maryland, v. 3, n. 4, p. 361-382, Dec.

HUNTINGTON, S. 1961. The Common Defense: Strategic Programs in National Politics. New York: Columbia University.

KRANSER, S. 1972. Are Bureaucracies Important? (Or Allison Wonderland). Foreign Policy, Washington (DC), n. 7, p. 159-179, Summer.

LASSWELL, H. \& KAPLAN, A. 1950. Power and Society. A Framework for Political Enquiry. New Heaven: Yale University.

LINS, C. E. 1999. Lafer atribui sua saída a tucanos e empresários. Folha de S. Paulo, 16.jul. Disponível em: http://www1.folha.uol.com.br/fsp/brasil/ fc16079906.htm. Acesso em: 23.abr.2013.

MCCUBBINS, M. \& SCHWARTZ, T. 1984.
Congressional Oversight Overlooked: Police patrol versus fire alarms. American Journal of Political Science, Bloomington, v. 28, n. 1, p. 165-179, Feb. Disponível em: http://www.unc.edu/ fbaum/ teaching/PLSC541_Fall08/mcubbins_schwartz_ 1984.pdf. Acesso em: 22.abr.2013.

MEIER, K. 1979. Politics and the Bureaucracy: Policymaking in the fourth branch of government. Pacific Grove: Duxbury.

MEIRELES, A. \& PEDROSA, M. 1999. A última vítima de Malan. Isto É, São Paulo, n. 1562, 8.set. Disponível em: http:/www.istoe.com.br/reportagens/33717_A+ULTIMA+VITIMA+DE+MALAN. Acesso em: 24.abr.2013.

MILLER, G. 2005. The Political Evolution of Principal-Agent Models. Annual Review of Political Science, Palo Alto, v. 8, p. 203-225, June.

MOE, T. 1984. The New Economics of Organization. American Journal of Political Science, Bloomington, v. 28, n. 4, p. 739-777, Nov. Disponível em: http:/eppam.weebly.com/uploads/5/5/6/ 2/5562069/new_economics_of_organization.pdf. Acesso em: 22.abr.2013.

1985. Control and Feedback in Economic Regulation: The case of the NLBR. The American Political Science Review, Los Angeles, v. 79, n. 4, p. 1094-1116, Dec.

MORAES, G. 2005. Dossiê Brasília. Os segredos dos presidentes. Rio de Janeiro: Globo.

NEUSTADT, R. 1960. Presidential Power. The politics of leadership. Hoboken: Wiley.

NISKANEN, W. 1971. Bureaucracy and Representative Government. New York: Atherton.

PETERS, G. 1995. The Politics of Bureaucracy. $4^{\mathrm{a}}$ ed. London: Longman.

PINTO, C. 1998. As novas tarefas da Camex. Folha de S. Paulo, 17.mar.

. O 'relançamento de Tápias'. Folha de S. Paulo, 24.fev.

PRADO, M. 2005. A real história do Plano Real. Uma radiografia da Moeda que mudou o Brasil. Rio de Janeiro: Record.

RAMOS, G. 2008. Comércio internacional, política comercial brasileira e a atuação da Câmara de Comércio Exterior (Camex) na condução das políticas para o setor. São Paulo. Dissertação (Mestrado em Administração). Fundação Getúlio Vargas.

ROSATI, J. 1981. Developing a Systematic Decision 
Making Framework: Bureaucratic politics in perspective. World Politics, Baltimore, v. 33, n. 2, p. 234-252, Jan.

ROURKE, F. 1979. Bureaucracy, Politics and Public Policy. Boston: Little Brown.

SCHILLING, W. 1962. The Politics of National Defense. In: SCHILLING, W. R.; HAMMOND, P. Y. \& SNYDER, G. H. Strategy, Politics and Defense Budgets. New York: Columbia University.

SCHNEIDER, B. 1993. The Career Connection: A comparative analysis of bureaucratic preferences and insulation. Comparative Politics, New York, v. 25, n. 3, p. 331-350, Apr.

1995. Burocracia pública e política industrial no Brasil. São Paulo: Sumaré.

SELZNICK, P. 1949. TVA and the Grass Roots. A study in the Sociology of Formal Organization. Erwing: University of California.

TULLOCK, G. 1965 The Politics of Bureaucracy. Washington (DC): Public Affairs.

VEIGA, P. 2007. Política comercial no Brasil: carac- terísticas, condicionantes domésticos e policymaking. In: JANK, M. S. \& SILVER, S. D. (orgs.). Politicas comerciais comparadas. Desempenho e Modelos Organizacionais. São Paulo: Singular.

VEIGA， P. \& IGLESIAS, R. 2002. A institucionalidade da politica brasileira de comércio exterior. Rio de Janeiro: FGV.

WEINGAST, B. 1984. The Congressional Bureaucratic System: A principal-agent perspective (with some applications to the SEC). Public Choice, New York, v. 44, n. 1, p. 147-191.

WEINGAST, B. \& MORAN, M. 1983. Bureaucratic Discretion or Congressional Control? Regulatory Policymaking by the Federal Trade Commission. Journal of Political Economy, Chicago, v. 91, n. 5, p. 765-800, Oct.

WELCH, D. 1992. The Organizational Process and Bureaucratic Politics Paradigm. Retrospect and Prospect. International Security, Cambridge (MA), v. 17, n. 2, p. 112-146, Autumn.

WILSON, J. 1989. Bureaucracy: What government agencies do and why they do it. New York: Basic.

\section{OUTRAS FONTES}

Empresários criticam discurso de ministro. 1999. Folha de S. Paulo, 5.jan.

Giannetti quer mais recursos para estimular exportações. 2000. Folha de S. Paulo, 3.mar.

Polêmica sobre o futuro. 1999. Época, São Paulo, n. 53, 24.maio. Disponível em: http://epoca.globo. com/edic/19990524/brasil1.htm. Acesso em: 24.abr.2013.

Substituições ficam para depois, diz Fernando Henrique Cardoso. 1998. Folha de S. Paulo, 25.nov. Disponível em: http://www1.folha.uol.com.br/fsp/brasil/ fc25119816.htm. Acesso em: 24.abr.2013.

\section{ANEXO}

\section{ENTREVISTAS REALIZADAS}

1. Mario Mugnaini Júnior. Secretário executivo da Camex (2003-2007). Diretor executivo da FIESP (2000-2002). Diretor executivo da Associação Brasileira de Indústria de Máquinas e Equipamentos (Abimaq) (2008). Presidente da Agência Paulista de Promoção de Investimentos e Competitividade Investe São Paulo (2009-2010) Entrevista realizada em: São Paulo, 29 de abril de 2010.

2. Roberto Giannetti da Fonseca. Secretário executivo da Camex (2000-02). Diretor do Departamento de Relações Internacionais e Comércio Exterior da FIESP e presidente da Fundação Centro de Estudos do Comércio Exterior (Funcex). Entrevista realizada em: São Paulo, 5 de maio de 2010.
3. Aloisio Tupinambá Gomes. Assessor especial da Camex (1999-2008). Entrevista realizada em: Brasília, 11 de maio de 2010.

4. Gustavo Saboia Fontenele e Silva. Chefe de gabinete da Camex. Analista de comércio exterior do MDIC desde 2001. Entrevista realizada em: Brasília, 12 de maio de 2010.

5. Fábio Martins Faria. Diretor do Departamento Departamento de Planejamento e Desenvolvimento do Comércio Exterior do MDIC. Entrevista realizada em: Brasília, 13 de maio de 2010.

6. Carlos Marcio Cozenday. Diplomata. Diretor do Departamento Econômico do MRE. Ex-assessor especial da Secretaria Executiva da Camex (1998- 
1999). Entrevista realizada em: Brasília, 13 de maio de 2010 .

7. Welber Barral. Secretário de comércio exterior do MDIC (2007-2011). Entrevista realizada em: Brasília, 14 de maio de 2010.

8. Anamélia Soccal Seyffarth. Assessora especial da Secretaria-Executiva da Camex desde 2004. Entrevista realizada em: Brasília, 14 de maio de 2010.

9. José Botafogo Gonçalves. Diplomata. Ministro da Indústria, do Comércio e do Turismo (1998). Embaixador do Brasil na Argentina (2002-2004). Representante Especial da presidência para o Mercosul (2001). Secretário executivo da Camex (2000). Subsecretário geral de Assuntos de Integração, Econômicos e de Comércio Exterior (1995-1998). Presidente do Conselho Curador do Centro Brasileiro de Relações Internacionais. Entrevista realizada em: Rio de Janeiro, 20 de maio de 2010.

10.Sérgio Silva do Amaral. Diplomata. Secretário de Assuntos Internacionais do Ministério da Fazenda
(1988-1989). Chefe do Gabinete do Ministério da Fazenda (1994). Ministro de Estado da Comunicação Social e porta-voz do Presidente da República (1995-1998). Ministro do Desenvolvimento, Indústria e Comércio Exterior e presidente da Camex (2001-2002). Entrevista realizada em: São Paulo, 21 de junho de 2010.

11. Celso Lafer. Professor da Faculdade de Direito da Universidade de São Paulo (USP). Ministro do Ministério das Relações Exteriores (1992 e 2001-2002) e MDIC (1999). Chefe da Missão Permanente do Brasil junto às Nações Unidas e à Organização Mundial do Comércio em Genebra (1995-1998). Entrevista realizada em: São Paulo, 7 e 22 de junho de 2010 .

12. Clóvis de Barros Carvalho. Secretário executivo do Ministério da Fazenda (1993-1994). Ministro da Casa Civil (1995-1999). Ministro do MDIC (1999). Secretário de Governo da Prefeitura de São Paulo de (2007-2010). Entrevista realizada em: São Paulo, 13 de julho de 2010. 